Document downloaded from:

http://hdl.handle.net/10251/84342

This paper must be cited as:

Penadés Gramage, MC.; Nuñez Avila, AG.; Canos Cerda, JH. (2017). From planning to resilience: The role (and value) of the emergency plan. Technological Forecasting and Social Change. 121(3):17-30. doi:10.1016/j.techfore.2016.12.004.

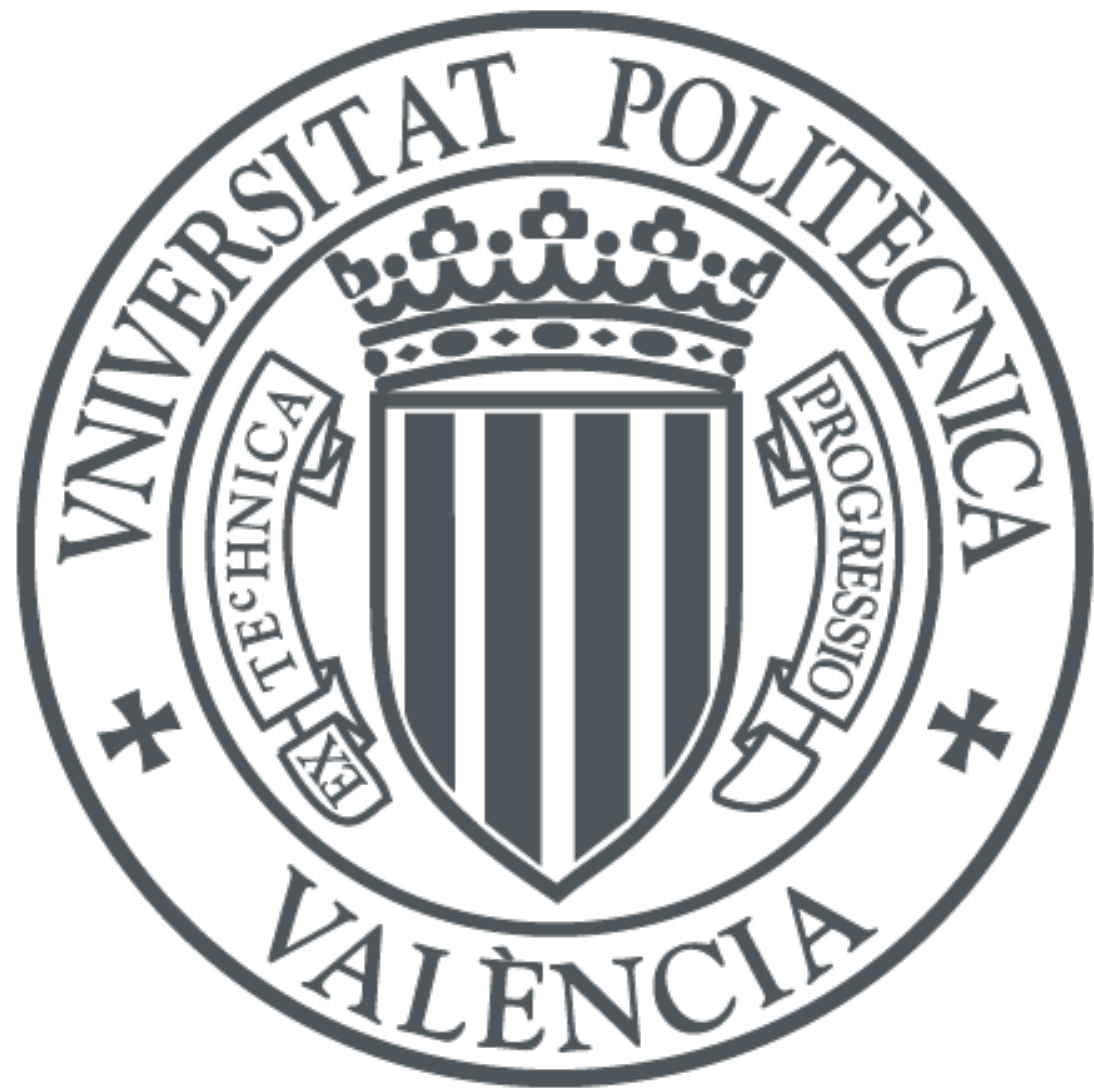

The final publication is available at

http://dx.doi.org/10.1016/j.techfore.2016.12.004

Copyright Elsevier

Additional Information

This is the author's version of a work that was accepted for publication in Technological Forecasting \& Social Change. Changes resulting from the publishing process, such as peer review, editing, corrections, structural formatting, and other quality control mechanisms may not be reflected in this document. Changes may have been made to this work since it was submitted for publication. A definitive version was subsequently published in Technological Forecasting \& Social Change 121 (2017) 17-30. DOI 10.1016/j.techfore.2016.12.004. 


\title{
From planning to resilience: the role (and value) of the emergency plan
}

\author{
M. Carmen Penadés, Ana G. Núñez, José H. Canós \\ ISSI-DSIC \\ Universitat Politècnica de València (Spain) \\ \{mpenades|anunez|jhcanos\}@dsic.upv.es
}

\begin{abstract}
The study of resilience in the emergency management field is nowadays in effervescence. Traditionally, the robustness of organizations against disasters is based on several pillars: equipment, staff training, organization and, especially, planning. All of these dimensions are aimed at increasing the preparedness and recovery of organizations against disasters. While the approaches to resilience in emergency management focus on the processes that implement these dimensions, we approach resilience-building processes from a different perspective: instead of focusing on planning-related activities, we pay attention to the principal outcome of such activities, namely emergency plan.
\end{abstract}

We show how the management of the emergency plan can contribute to reinforcing an organization's resilience. First, we identify the major resilience-related emergency plan components and suggest improved emergency plans that consider the characteristics that contribute to resilience. Secondly, we show how to reinforce the resilience of the organizations that have emergency plans. Our study is based on QuEP, a quality-based framework for the assessment and improvement of emergency plan management within organizations. We have extended and integrated the resilience characteristics as practices of the QuEP's maturity level hierarchy to make up QuEP+R. We describe its resilience model and give details of a supporting tool, currently under development.

\section{Keywords}

Emergency Plan Management, Resilience, Quality Management, Maturity levels, QuEP.

\section{Introduction and motivation}

The growing frequency of natural and manmade disasters has raised the concern of communities about their capacity for response. As a consequence, these communities and their governments have turned their attention to the methods, techniques and tools for increasing their preparedness against all types of adverse events. The importance of the problem on a global level has triggered the development of a number of studies aimed at increasing communities' resilience, like The Hyogo Framework for Action 2005-2015 (UNISDR, 2005), created by the United Nations Organization. Most of these studies focus on disaster management and how organizations improve their responses to hazards. In (Manyena, 2006; Bhamra et al., 2013; Alexander, 2013) some resilience definitions are summarized and discussed in relation to disaster management.

Improving emergency preparedness has also been a long term goal of the Emergency Management community. In fact, it is generally agreed that preparedness is one of the main stages of the emergency management lifecycle (Blanchard, 2008; Lindsay, 2012). Although preparedness has planning as its main activity, it also includes resource management, 
potential threats identification and training, among others. The main outcome of the preparedness stage is the emergency plan, which is considered the central element of the entire emergency management lifecycle and the source of the formal knowledge managed during responses (Diniz et al., 2008).

Although McEntire et al. acknowledge the importance of emergency preparedness activities in this resilience building process (McEntire et al., 2002), the relationship between emergency preparedness and resilience building has not been made explicit in the literature. For instance, search in the ISCRAM Digital Library", including the keyword "resilience" returned 40 papers out of $1261^{2}$. On the other hand, while 81 papers have "planning" as (part of) a keyword, only 3 papers also include "resilience".

Putting planning and resilience together yields a new perspective on the resilience building processes. We argue that there is a strong relationship between emergency preparedness and resilience building. To explore this relationship, we focus on the emergency plan and study its effects on resilience. Assuming that for an organization having an emergency plan does not necessarily mean it is being resilient, we determine to what extent the components and characteristics of the emergency plan can be a good indicator of the theoretical resilience of organizations. We call it theoretical, since emergency plans are just plans. How effective they are will depend mostly on how the organization uses the knowledge included in the emergency plans to actually become more resilient. In other words: the theoretical resilience must be transformed by organizations into actual resilience; people can (or should) acquire an adaptive behaviour against disasters by applying the policies described in the emergency plans. For different reasons, it is quite unusual for all the policies in an emergency plan to be properly executed (Kean et al., 2004). As a consequence, good levels of theoretical resilience do not necessarily mean good levels of actual resilience. From this perspective, a one-to-one ratio between theoretical and actual resilience is a goal rather than a fact. The present study is therefore not restricted to the emergency plan only, but also includes its management.

We analyze the relationship between the emergency plan and both the theoretical and actual types of resilience from a conceptual point of view. We want to explore how concepts from the resilience field relate with those of emergency planning, and provide a model to evaluate the theoretical/actual resilience of an organization from the analysis of the management of its emergency plan. As the first step, we study how much theoretical resilience current emergency plans contain. This is the key to assessing how much the content and structure of emergency plans contribute to increasing an organization's resilience. To address this issue, we start from the definition of resilience given by Fiksel (Fiksel, 2003), who pointed out the existence of several dimensions (or characteristics) that contribute to resilience, which may be interpreted in a wide context (product, enterprise or nested systems). These characteristics are:

“(..)

- diversity: the existence of multiple forms and behaviours

- efficiency - performance with modest resource consumption

1The ISCRAM Digital Library is owned by the International Association of Information Systems for Crisis Response and Management, and holds the proceedings of the International Conference on Information Systems for Crisis Response and Management since its first edition. It can be accessed at http://idl.iscram.org

${ }^{2}$ As of September 19, 2016 
- adaptability - flexibility to change in response to new pressures

- cohesion - existence of unifying relationships and linkages between system variables and elements." (Quoted from (Fiksel, 2003), page 5333).

If we look at current emergency plans, we see they are far from showing most of the above characteristics. In general, they are text-based, monolithic documents that give little evidence of either diversity or efficiency. In many cases, their structures and basic contents are based on law, which is not flexible enough to cope with unexpected changes, making adaptability difficult. However, the concept of an emergency plan has high potential, if properly developed, to contribute significantly to increasing an organization's resilience (Penadés et al., 2011; Canós et al., 2013; Turoff et al., 2013).

Consequently, our first goal is to find ways to make emergency plans more resilient in the sense of Fiksel's model. We define a framework based on the dimensions of emergency response defined in (Canós et al., 2004). For each dimension, we identify a number of features and identify the ones that contribute to Fiksel's characteristics and possible ways of improving the level of achievement of the characteristics within each feature.

Having resilient emergency plans is not by itself enough to improve the resilience of an organization: in order to be useful, emergency plans must be well managed. Our second goal is thus to find the aspects of emergency plan management that are related to resilience. To achieve this goal, we rely on QuEP (Nuñez et al., 2015; Nuñez et al., 2016a), a framework inspired by the Total Quality Management strategy (Charantimath, 2011; Oakland, 2014), which assesses the emergency plan management capabilities of organizations according to a hierarchy of maturity levels. We explore the relationship between the QuEP principles and practices with Fiksel's resilience characteristics and analyze the factors that contribute to resilience.

The remainder of this paper is organized as follows. Section 2 provides a view of the background to resilience in different domains and how it is measured by characteristicsbased quantification. Section 3 analyzes the emergency plan management domain to identify the actions that increase and reduce resilience. In Section 4 we describe the features that emergency plans should include to enforce resilience, and in Section 5 we introduce the QuEP framework and how to integrate resilience as a new dimension to be measured in the assessment and improvement of emergency plan management, supported by an IT-based tool. Section 6 gives our conclusions and outlines further work.

\section{Background}

The capability and ability of an element to adapt and return to a stable state after a disruption are closely related to the concept of resilience. Originally developed as an ecological concept (Holling et al., 1973), resilience was applied to other contexts and domains, enriched with a social (Adger, 1997) or organizational dimension (Timmerman, 1981). Nowadays, resilience is related to both the individual and organisational responses to disturbances and the term is used in different contexts and domains. In (Manyena, 2006; Bhamra et al., 2013; Alexander, 2013), the authors summarize the most widely recognized definitions of resilience and their contextualization in each domain. These definitions often include a number of properties that characterize resilience. For instance, if we review the term "resilience" in the earliest works in the ecology and society domains, the study is 
focused on aspects of socio-ecological systems, such as persistence, adaptability and transformability to adapt to continuous change and earth threats. The properties identified to characterize resilience include latitude, resistance, precariousness and cross-scale relations, among others (Folke et al., 2004) or, in terms of absorption of disturbances, selforganization, and learning and adaptation (Walker et al., 2002). Another pioneering field in resilience was the psychology domain (Werner, 1995); in this case, the studies focused on how resilience affects individuals in adversity and their positive adaptation from everyday situations to major life events through psychological characteristics in stress process contexts. Fletcher and Sarkar identified certain resilience factors, such as positive personality, motivation, confidence, focus and perceived social support (Fletcher and Sarkar, 2013).

The properties identified to characterize resilience provide a good approach to measuring resilience. Brown identifies five such approaches: quantification based on functionality is applied to computer systems or infrastructures and engineering (Brown, 2013). Quantification based on food access is applied to the household economy domain. Activitybased measurement is focused on people's resilience according to different investments and has very limited applications. The quantification derived from theoretical resilience is based on theoretical frameworks. Finally, the measurement based on characteristics consists of deriving indicators from the characteristics of resilience and assuming that if they are improved, resilience itself is also improved. In fact, the first resilience system was defined as the measure of a system's persistence and ability to absorb disturbances (Holling, 1973). Klein also emphasizes the importance of measuring and improving resilience through clear and good indicators (Kein et al., 2003).

\subsection{Resilience in Emergency Management}

The concept of resilience is new to the emergency management arena after decades of growth in different domains. Crichton et al. point out the relevance of the lessons learned in the development of organizational resilience and recommend adopting a cross-domain strategy, since experiences in other domains can be exported to a new one (Crichton, Ramsay and Kelly, 2009). Here we review some studies in the organizational domain and the strategic management domain according to Crichton's criteria, because we consider them to have an influence on emergency management resilience.

In the organizational domain, research is related to safety engineering (Hollnagel and Woods, 2006; Adolph, 2012), for which the resilience concept is focused on the study of safety and how, in spite of people in organizations having to work under pressure, the situations are resolved successfully. In this domain, the main resilience factors are resources (culture, financial, strong networks, intellectual, human and physical assets) and adaptive skills (leadership, adaptive capacity, awareness of environment, management of vulnerabilities) (Nwachukwu and Robinson, 2011). In the strategic management domain, resilience is also defined as the ability to dynamically reinvent business models and strategies as circumstances change (Hamel and Valikangas, 2003).

On the other hand, the definition of resilience contextualized for the emergency management domain is clearly influenced by previous studies on the disaster risk-reduction domain (Manyena, 2006; Zhou, 2010; Alexander, 2013), for which the United Nations International Strategy for Disaster Risk Reduction (UNISDR) provides the definition: "The ability of a 
system, community or society exposed to hazards to resist, absorb, accommodate to and recover from the effects of a hazard in a timely and efficient manner, including through the preservation and restoration of its essential basic structures and functions" (UNISDR, 2009, p.24).The factors influencing resilience are physical, economic, human, environmental, social, political and cultural (Turnbull et al., 2013). Other studies related to resilience in a disaster are those by Baharmand and Meesters, who analyzed aspects of community resilience such as persistence, adaptability and transformability (Baharmand and Meesters, 2016), or Sakurai, who proposes a capital model for disaster resilience in which the organization is viewed as a capital conversion and creation system (Sakurai et al., 2016). There are also studies on resilience in a particular situation (an emergency event, training exercise, etc.). For instance, Berggren's work shows "an approach to team training for nuclear power plant control room teams with the purpose of making the system more resilient" (Berggren et al., 2016). Huber et al. described a simulated firefighting emergency response exercise with a relationship between standardization and resilience (Huber et al., 2016). Reis et al. pointed out the advantages of identifying resilient actions from successful responses and their inclusion in the organization's emergency plans (dos Reis et al., 2008). Finally, Zobel is one of the few studies that propose two measures of disaster resilience, based on the initial impact of the event and the recovery time (Zobel, 2011).

However, to the best of our knowledge, there are as yet no studies on resilience in emergency plan management, which is the aim of the present paper. Our intention is not only to define the concept of resilience within this domain, but to identify the factors, characteristics or capabilities that are related to a resilient view of emergency plans and their management and so obtain a measure of resilience.

\section{Identifying Resilience in the Emergency Plan Management context}

Governments and business organizations adopt resilience principles in order to achieve a sustainable future. According to Fiksel et al. sustainability will come about from a number of actions aimed at promoting the anticipation of change, understanding early warning signals, and taking steps to avoid and/or mitigate future problems (Fiksel et al., 2014). These are roughly the same emergency preparedness goals as those defined in (Blanchard, 2008, pp. 373). Due to this similarity, studying the relevance of the instruments that provide emergency preparedness to organizations as generators of resilience, we can establish links between the research fields of Emergency Plan Management and Resilience.

Organizations must be able to respond to changes by adapting themselves to new contexts and managing risk and perturbation variability (Sigel, 2015). As a consequence, if we focus on risk management as an important part of planning, we can see that the emergency plan management should contain the risks identified, along with the practices applied and how the actors are coordinated to reduce each risk (Turnbull et al., 2013). Although classical risk management remains an important method of dealing with familiar issues such as fires, accidents, diseases, and currency fluctuations, it is very important to include the study of resilience in addressing complex situations, such as climate change and the loss of biodiversity (Fiksel et al., 2014). These new threats have made organizations prepare for eventual complex situations, going beyond the classical risk management methods and 
techniques in order to avoid as many human, economic and environmental disruptions as possible (Fiksel, 2006).

We adopted a systems approach to the resilience of emergency plans and their management. Our vision of the emergency plan management domain as a complex system is summarized in Figure 1. Inspired by the 3V model (Fiksel, 2012), we identify three major components (organization, community and environment) and model the main links between them. An organization must be able to analyze threats, vulnerabilities and risks affecting people and/or infrastructures; such threats come from the organization's environment, being the result of either natural phenomena or human actions. Therefore, the organization must enforce the active engagement of the community it serves, by supporting the training of citizens, workers, and responders, etc. to face risk situations. Moreover, the community itself must participate in the development and improvement of the organization's emergency plan.

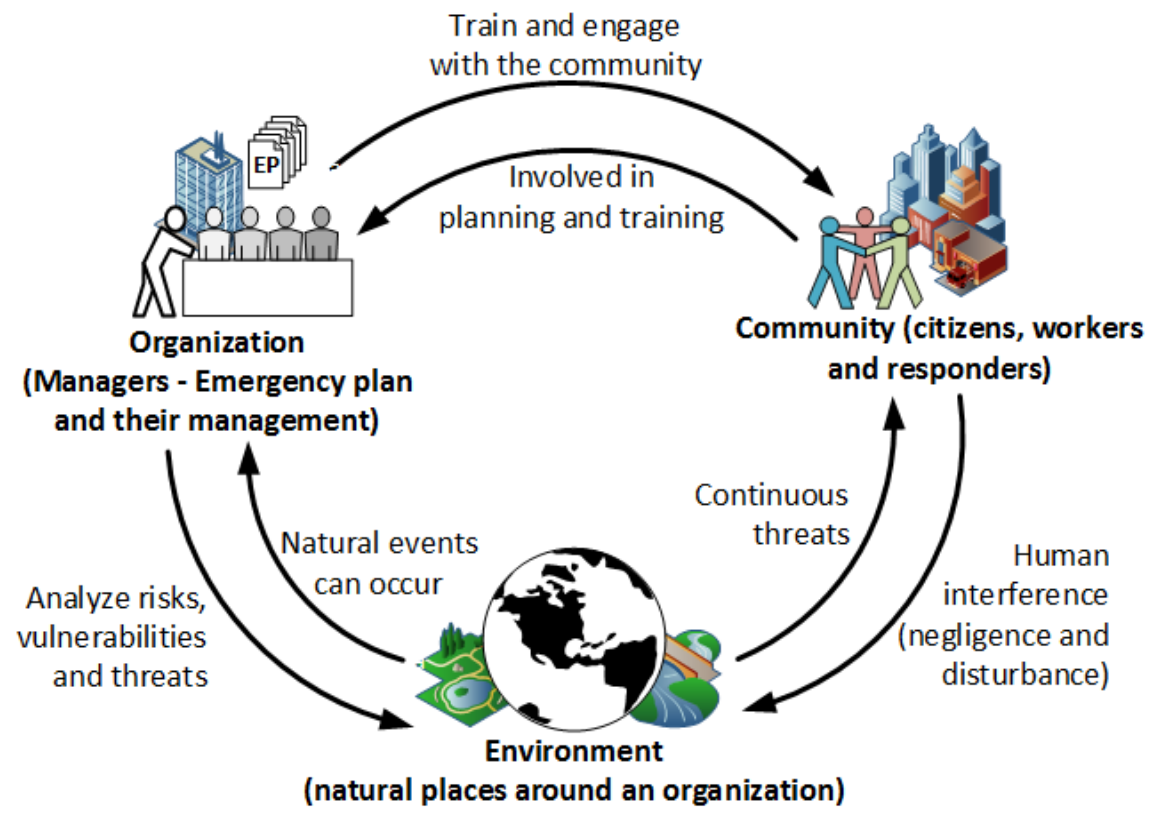

Figure 1. Emergency Plans Management Model

Such a domain model is the starting point of our analysis, which aims to find the system components related to resilience, and then identify the actions that increase or reduce it. For instance, having a printed emergency plan is less resilient than having it as a hypermedia document stored in a digital library, since in the latter case the linkage between organization and community is reinforced (better planning, training, etc.) and the system capacity to adapt, recover and go back to normal is increased. Therefore, an action like improving the emergency plan (from textual to hypermedia) increases the resilience of the system.

We follow the four characteristics of resilient systems (diversity, efficiency, adaptability and cohesion) proposed by Fiksel (Fiksel, 2003) and adapt these characteristics to the emergency plan management domain. These characteristics of resilient systems are important when the disruptions or discontinuities return to their original state. These disruptions may occur when introducing new regulations, new technologies, emergency events, changes in the availability of new resources, adjustments to budgets and costs, 
among others. Fiksel's resilience characteristics can be analyzed on different levels: product, enterprise, ecosystem and the socio-economic system.

According to this view, we consider the resilience of emergency plan management as a change process of the system, based on a set of characteristics which will be applied to it or which will affect it. The analysis of resilience through these characteristics can be measured and improved. We address the study of the resilience of emergency plan management in two stages. In the first stage, we identify how to improve the resilience of emergency plans, and in the second we analyze how to enforce the resilience of emergency plan management using the QuEP quality-based framework and incorporating resilience into the assessment and improvement of the organizations.

\section{Towards more resilient Emergency Plans}

To find ways to make emergency plans more resilient, we need to understand what an emergency plan provides, and analyze it with regard to the characteristics of resilient systems. To understand what an emergency plan should contain, Canós et al. enumerated a set of dimensions derived from the nature of crisis responses (Canós et al., 2004). Each dimension corresponds to one row of Table 1.

\begin{tabular}{|c|c|c|c|c|}
\hline \multirow{2}{*}{$\begin{array}{l}\text { Dimensions of } \\
\text { emergency } \\
\text { response }\end{array}$} & \multicolumn{4}{|c|}{ System Characteristics of Resilience for Emergency Plans [Fiksel] } \\
\hline & C1. Diversity. & C2. Efficiency & C3. Adaptability & C4. Cohesion \\
\hline $\begin{array}{l}\text { D1. } \\
\text { Coordination }\end{array}$ & $\begin{array}{l}\text { - Different notations to } \\
\text { represent the } \\
\text { emergency responses } \\
\text { processes } \\
\text { - Customized process } \\
\text { views }\end{array}$ & $\begin{array}{l}\text { - Improvement of } \\
\text { response processes } \\
\text { - Executable response } \\
\text { processes }\end{array}$ & $\begin{array}{l}\text { - Flexible workflow } \\
\text { languages } \\
\text { - Case management } \\
\text { modelling languages }\end{array}$ & $\begin{array}{l}\text { - Emergency } \\
\text { Management Support } \\
\text { System } \\
\text { - Stakeholders } \\
\text { relationships } \\
\text { - Safety people }\end{array}$ \\
\hline $\begin{array}{l}\text { D2. } \\
\text { Information }\end{array}$ & $\begin{array}{l}\text { - Formal and } \\
\text { Contextual } \\
\text { Knowledge } \\
\text { - Information integration } \\
\text { - Ontologies }\end{array}$ & - Digital Libraries & $\begin{array}{l}\text { - Context- } \\
\text { sensitiveness }\end{array}$ & $\begin{array}{l}\text { - Safety oriented } \\
\text { information systems } \\
\text { - Emergency context } \\
\text { - Social networks }\end{array}$ \\
\hline $\begin{array}{l}\text { D3. } \\
\text { Presentation }\end{array}$ & $\begin{array}{l}\text { - Personalized views of } \\
\text { emergency plans }\end{array}$ & $\begin{array}{l}\text { - Automatic } \\
\text { dissemination of } \\
\text { information as } \\
\text { multimedia digital } \\
\text { objects }\end{array}$ & - Adaptive Interfaces & $\begin{array}{l}\text { - Emergency context } \\
\text { integrated (experts) } \\
\text { - Social Networks } \\
\text { integrated }\end{array}$ \\
\hline $\begin{array}{l}\text { D4. } \\
\text { Collaboration }\end{array}$ & $\begin{array}{l}\text { - Role-based intra/inter } \\
\text { organizational } \\
\text { coordination levels. }\end{array}$ & $\begin{array}{l}\text { - Training } \\
\text { - Collaborative decision } \\
\text { support system }\end{array}$ & $\begin{array}{l}\text { - Learning } \\
\text { - Resources allocation } \\
\text { - Continuous support of } \\
\text { information in real- } \\
\text { time }\end{array}$ & $\begin{array}{l}\text { - Corporate culture } \\
\text { - Intra/Inter } \\
\text { organizational } \\
\text { coordination } \\
\text { - Safety awareness }\end{array}$ \\
\hline $\begin{array}{l}\text { D5. } \\
\text { Communication }\end{array}$ & $\begin{array}{l}\text { - Different } \\
\text { devices/channels } \\
\text { - Interoperability }\end{array}$ & $\begin{array}{l}\text { - Cloud services and } \\
\text { ubiquitous computing }\end{array}$ & $\begin{array}{l}\text { - Allocation of resource } \\
\text { buffer for critical } \\
\text { situations }\end{array}$ & $\begin{array}{l}\text { - Integrated } \\
\text { communication } \\
\text { system } \\
\text { - Transfer, fast, and } \\
\text { reliable } \\
\text { communication of } \\
\text { information }\end{array}$ \\
\hline $\begin{array}{l}\text { D6. } \\
\text { Intelligence }\end{array}$ & $\begin{array}{l}\text { - Different data sources } \\
\text { \& algorithms }\end{array}$ & $\begin{array}{l}\text { - Data Warehouse \& } \\
\text { Data Mining } \\
\text { - Data Science } \\
\text { - Decision support } \\
\text { systems }\end{array}$ & $\begin{array}{l}\text { - Context-sensitive } \\
\text { tools } \\
\text { - Ambient intelligence } \\
\text { environments }\end{array}$ & $\begin{array}{l}\text { - Information } \\
\text { consolidated from } \\
\text { data sources }\end{array}$ \\
\hline
\end{tabular}

Table 1. Identifying Resilience of Emergency Plans by Emergency Response Dimensions 
In general, a response is a process where a number of actors act according to certain protocols (coordination); during their performance, they need to have access to different pieces of relevant information, which must be managed in order to be provided in the right way to the right actor (information management and presentation). Part of the information can be contained in the emergency plan, whereas other parts may come in almost real time from the context of the emergency (that is, different information sources collecting data, images, people's messages, etc.) and need to be processed by different techniques (intelligence) and used in individual or collective decision-making processes (collaboration). Additionally, some communication mechanisms need to be in place to support the other dimensions.

We studied the dimensions of emergency response in terms of the Fiksel's resilient characteristics. The four characteristics are represented in the columns in Table 1. The cells in the Table outline the features that emergency plans should include to enforce each dimension with respect to the resilient characteristics and to enforce the theoretical resilience. We discuss the Table 1 in detail in the following subsections.

\subsection{Coordination}

A response plan is executed at the core of every emergency response. Such a response plan is the specification in language of a process involving different actors, possibly playing different roles, that perform certain activities in a coordinated way. The control and data flows between the activities provide the coordination and information flow of the response, respectively. The coordination capability of an organization can be directly related to the diversity of the expressiveness of the coordination languages used. Natural language procedure descriptions are by far the most common in current response plans, despite the limitations inherent in the language used, prone to ambiguity and ellipsis that can hide important guidelines. Graphical descriptions are a way of systematizing the definition of the responses. And things become much more rigorous when process semantics are added to the graphical descriptions (e.g. via a workflow specification language).

Besides the enhanced expressiveness of a process language, the execution support provided by the underlying process engine may increase the efficiency of the process. However, workflow-based process specifications suffer from a lack of flexibility that crisis situations require. Some researchers advocate adaptability to unexpected situations by using flexible workflow languages (Bruinsma, 2010; Canós et al., 2014; Llavador et al., 2006). The cohesion provided by the coordination mechanisms comes from the fact that a response is viewed as the execution of a process, with all the participants represented as entities in the process model. The more expressive the modelling language is, the more cohesive is the approach: in the best cases, an emergency management support system, such as SAGA (Canós et al., 2013), will have a (flexible) process engine able to control, dispatch and support the different activities according to the response procedure specification.

\subsection{Information management}

Emergency responses are, to a large extent, knowledge intensive processes (Canós et al., 2014). Most of the decisions taken during a response process are based on the knowledge of the decision makers about a particular situation. This knowledge comes from a variety of 
sources, as explained in (Diniz et al., 2008). Formal knowledge is obtained from the emergency plan, while contextual knowledge is gathered in place by different actors (responders, members of the public, or sensor networks). When both formal and contextual knowledge are lacking in a given situation, responders can base their decisions on their personal experience in similar situations.

The diversity of knowledge sources can be tackled by combining all the information sources by means of information integration systems (e.g. data mashups (Schulz and Paulheim, 2013)), where semantic gaps between the different knowledge sources can be reduced by using ontologies (Galton and Worboys, 2011). The efficiency of knowledge access can be improved by using an information infrastructure in the form of Multimedia Digital Objects, as in the case of Digital Libraries. The adaptability of such infrastructures can come from the appropriate mechanisms to combine formal and contextual knowledge, as suggested in (Solís and Ali, 2008; Canós et al., 2010). Safety-oriented information systems, powered by digital library technology and extended with context-processing facilities, can provide the glue required by integrated emergency responses.

\subsection{Presentation}

Having the right information must be complemented by having it in the right way. A classical limitation of current emergency plans is their monolithic nature: they are compiled in a text document that is shared by all the stakeholders. As a consequence, some users of the emergency plan may experience confusion when handling information that may be too specific for their mission in the response. The complexity of a building map including all the technical equipment, designed by and for responders, may not be recommendable as an evacuation guidance tool by the users. And in some cases, contextual information must be shown on top of the formal knowledge, since the latter may be obsolete (for instance, when a collapsed roof makes an evacuation route impossible). The presentation of information is therefore a crucial issue.

Resilient emergency plans should take into account the diversity of information users and be able to provide selective, actor-driven information dissemination. The configuration of the selective dissemination must be one of the emergency plan design activities. The research agenda must include extensions of the executable process definition languages, allowing the association of tasks with their digital objects and the automatic management of such associations (Sánchez et al., 2015). Sometimes, the information source is external to an organization, which impedes cohesive integration. In these cases, external sources (e.g. the social networks) can be queried and processed via the corresponding APIs by social network analysis tools (Li and Goodchild, 2010).

\subsection{Collaboration}

Collaboration is inherent in an emergency response, in which different actors playing different roles need to act together according to protocols in order to cover all the aspects of a response (e.g. fire extinguishing, saving lives, medical attention, food provision, etc.). In some cases, critical decisions can only be the result of the agreement of experts in different areas, who share their views and obtain feedback from each other. In cases where the diversity of roles leads to collaborative decision making, diversity must be combined with collaborative tool support (Mills, 2003). 


\subsection{Communication}

In this context, communication facilities must guarantee the availability of all the other dimensions, especially personal information delivery and collaborative support, as well as coordination when no automatic process enactment is available. As we consider communication an infrastructure issue, we will not deal with it in the remainder of this paper. However, as Table 1 shows, certain issues must be dealt with when studying the resilience of emergency plans, including how to deploy advanced (or highly resilient) emergency plans in cloud platforms (Miller, 2006).

\subsection{Intelligence}

In our context, intelligence means the ability to generate and provide knowledge. In terms of diversity, this ability is achieved by gathering data from different sources and performing the fusion required to satisfy the responders' informational needs. The main source is the emergency plan itself, which stores the formal knowledge. Other sources of formal knowledge can be e.g. map servers, or open government data sets. Regarding contextual knowledge, different sources such as weather forecasts, the status of the evacuation paths (Hofmann et al., 2013; Canós et al., 2014), or even the content published by citizens in social networks can be of high value in making a decision (Villena-Román et al., 2014).

The use of advanced data management techniques and tools (e.g. Data Warehousing and Data Mining (Han et al., 2011)) and the availability of decision-support facilities are key to increasing the efficiency of the responses (Mendonça, 2007). Adaptability, in turn, means the ability to support decision makers in different circumstances. This may include the ability to interact with the emergency plan through different devices, or even languages, as well as the seamless integration of different ambient intelligence devices providing data to different types of responders. In the end, intelligence brings cohesion to the emergency plan in the sense that formal and contextual knowledge sources can be merged, so that a coherent view of the emergency situation can be provided to the response forces.

\section{Towards Resilient Emergency Plan Management}

The emergency plan is the central piece of emergency management, but having resilient emergency plans is not enough for an organization to be resilient. In our view, building resilience is an activity present in all emergency plans, enabling theoretical resilience be transformed into actual resilience, and we therefore address the second question.

To find the aspects of emergency plan management related to resilience, we need to analyze the activities involved in the management of emergency plans and explore their relationships with the characteristics of resilient systems. We base our analysis of emergency plan management on the QuEP framework (Nuñez et al., 2015; Nuñez et al., 2016a) which evaluates the planning process and analyses the capabilities and all activities involved before, during and after the process of developing an emergency plan following a Total Quality Management (TQM) strategy (Charantimath, 2011; Oakland, 2014). We will compose QuEP maturity levels and principles with Fiksel's resilience characteristics to find out how adequate emergency plan management can contribute to making an organization more resilient. 


\subsection{The QuEP framework}

QuEP (Nuñez et al., 2015; Nuñez et al., 2016a) is a framework for the assessment and improvement of emergency plan management within organizations. QuEP is inspired by the TQM approach. QuEP's core is a hierarchy of maturity levels defined in terms of principles, practices and techniques (Dean and Bowen, 1994; Mandal, 2009). It is viewed as a continuous way of life and a philosophy of perpetual improvement in everything an organization does. The QuEP framework is based on the study of quality aspects of a good emergency plan (Alexander, 2005; Berke and Godschalk, 2009; Berke et al., 2012; Meyerson, 2012).

\section{The QuEP Maturity Levels hierarchy}

QuEP is composed of ten maturity levels ranging from Level 1 (the lowest level) to Level 10 (the highest). The maturity level hierarchy is depicted in Figure 2. Following (Camisón, 1998, 2007), the levels can be grouped into three main categories or stages, namely: Technical, Human, and Strategic.

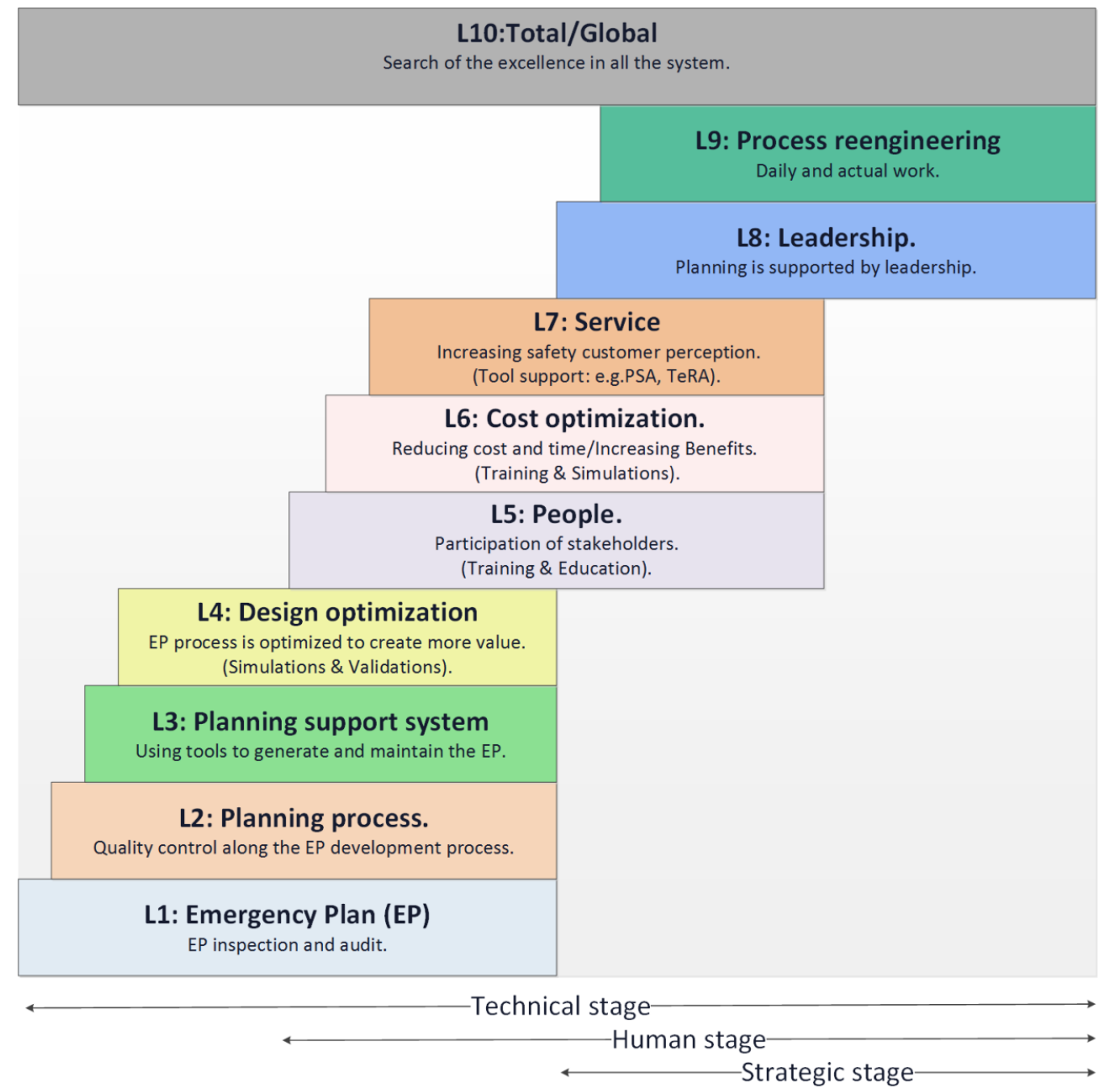

Figure 2. QuEP Maturity Levels 
The hierarchy starts at the lowest maturity level (L1), which assesses the organization's ability to generate an emergency plan following the regulations, if any. L1 organizations have not defined any structured plan generation process, and planning is done in an ad-hoc style. The upper levels can be reached by means of different improvements. L2 organizations have a specific and repeatable planning process that guides the planning activities. L3 maturity level is reached when a planning support system is used that implements the process defined in L2. Organizations at L4 maturity level have different mechanisms for the improvement of the planning process and the emergency plan itself, such as simulations and expert validation. L5 maturity level assesses the participation of the people involved in emergency plan generation and enactment, principally via training and education activities. Cost optimization is the main goal at the L6 maturity level. The L7 maturity level focuses on increased safety perception by potential victims of emergencies, which can be achieved by providing IT tools for early warning, evacuation assistants and the like. Level L8 covers leadership aspects and L9 uses process re-engineering techniques to improve the emergency planning process. The topmost level (L10) represents the excellence that an organization should reach to achieve Total Quality. The QuEP maturity levels are supported by a model to assess the planning process in an organization, called the QuEP model. This model is defined in terms of sets of principles, practices, techniques and questions.

\section{The QUEP Principles}

QuEP is composed of nine principles that guide the emergency plan management process according to the different viewpoints of the stakeholders involved in the emergency plan management activities and their responsibilities or roles (Turoff et al., 2004; Turner, 1976). QuEP recognizes five different stakeholders, listed in Table 2.

\begin{tabular}{|l|l|}
\hline Stakeholders & Responsibilities \\
\hline (Org.) Organization & $\begin{array}{l}\text { - Access to emergency management legislation. } \\
\text { - Emergency plan registration. } \\
\text { - Validation. } \\
\text { - Education. }\end{array}$ \\
\hline (Pla.) Planners & $\begin{array}{l}\text { - Emergency plan design and generation. } \\
\text { - Use of planning support tools. }\end{array}$ \\
\hline (Wrk.) Workers & $\begin{array}{l}\text { - Participation in the planning activities. } \\
\text { - Education and training. }\end{array}$ \\
\hline (Rsp.) Responders & $\begin{array}{l}\text { - Access to emergency plan. } \\
\text { - Education and training. } \\
\text { - Response. }\end{array}$ \\
\hline (Cit.) Citizens & $\begin{array}{l}\text { - Access to emergency plans. } \\
\text { - To follow the instructions of responders. }\end{array}$ \\
\hline
\end{tabular}

Table 2. QuEP Roles: Stakeholders and their responsibilities

The organization managers are those ultimately responsible for plan management, and are thus mostly involved in administrative and strategic tasks. The technical aspects of plan management are the responsibility of planners, who use tools with different levels of sophistication to build the emergency plans. The organization staff, i.e. the people that work in the different departments of the organization, are involved in training activities, so that their preparedness is at the highest level at all times. The citizens, that is, the users of the 
services provided by the organization, must be able to access the parts of the emergency plan required for their self-protection. And finally, the members of the different response teams need to access the parts of the emergency plan that contain information related to their specialities, as well as to participate in training sessions, if necessary.

We defined the nine QuEP principles according to the different viewpoints involved in the development and maintenance of emergency plans (see Table 3). First of all, the development of any emergency plan must be driven by the risks affecting the organization. The emergency plan must clearly define how it should be implemented. Additionally, all the stakeholders must participate in one way or another in the management of the emergency plan according to their responsibilities. The quality of a plan must be continuously assessed and, if possible, improved and is the result of the collaboration of the different stakeholders at intra and inter-organizational levels, sometimes resulting in emergency plans built by the combination of different component plans.

\begin{tabular}{|c|c|}
\hline \multicolumn{2}{|l|}{ QuEP Principles } \\
\hline (A) Risk Driven & $\begin{array}{l}\text { The emergency plan is based on the analysis and study of the } \\
\text { risks associated to a given organization. }\end{array}$ \\
\hline (B) Implementation & $\begin{array}{l}\text { The emergency plan must clearly define how it should be } \\
\text { implemented. }\end{array}$ \\
\hline (C) Participation & $\begin{array}{l}\text { The emergency plan should be developed with participation of all } \\
\text { the stakeholders. }\end{array}$ \\
\hline $\begin{array}{l}\text { (D) Monitoring and } \\
\text { Continuous improvement }\end{array}$ & The emergency plan must continuously be evaluated and revised. \\
\hline (E) Cooperation & $\begin{array}{l}\text { Inter-organizational coordination is key in emergency } \\
\text { management, resulting sometimes in joint emergency plans. }\end{array}$ \\
\hline (F) Safety People & $\begin{array}{l}\text { The emergency plan elaboration must take cultural aspects into } \\
\text { account. }\end{array}$ \\
\hline $\begin{array}{l}\text { (G) Leadership and } \\
\text { Policies. }\end{array}$ & $\begin{array}{l}\text { Risk and emergency management are very important axes within } \\
\text { an organization and, as such, an emergency plan must include } \\
\text { policies to handle them. }\end{array}$ \\
\hline (H) Results of objectives & $\begin{array}{l}\text { Goals must be clearly stated and work must be oriented to their } \\
\text { fulfilment. }\end{array}$ \\
\hline (I) IT \& Innovation & $\begin{array}{l}\text { Information technology significantly improves emergency plan } \\
\text { development. }\end{array}$ \\
\hline
\end{tabular}

Table 3. QuEP Principles

As the goal of a plan is to be an instrument for people's protection, every social and cultural aspect of protection needs to be considered. Similarly, having clearly defined protection policies within an organization is crucial for the development of the plan. Such policies should be defined as a response to the strategic goals the organization sets at the beginning of the process. Last, but not least, the use of IT-based tools may result in a significant 
qualitative improvement in the efficacy of emergency plans. Due to space limitations, in this paper we will focus on two principles, namely the (A) Risk Driven principle and the (D) Monitoring and Continuous improvement principle or Monitoring principle for short.

\section{QuEP-based Assessment and Improvement of Emergency Plans Management}

QuEP is defined as a two-dimensional framework. The relationship between maturity levels and principles is specified in order to identify the capabilities of an organization that should be assessed at each level and how they can be improved. Figure 3 shows the assessment criteria at each maturity level forthe $(A)$ Risk Driven and the (D) Monitoring principles. Notice how, for each maturity level, certain criteria are used to assess the organization's capabilities with regard to each principle. On the other hand, while the $(A)$ Risk Driven principle has assessment criteria defined for all the maturity levels, no criteria are included for L1 to L3 maturity levels for the $(D)$ Monitoring principle, since there must be an emergency plan to start its continuous improvement.

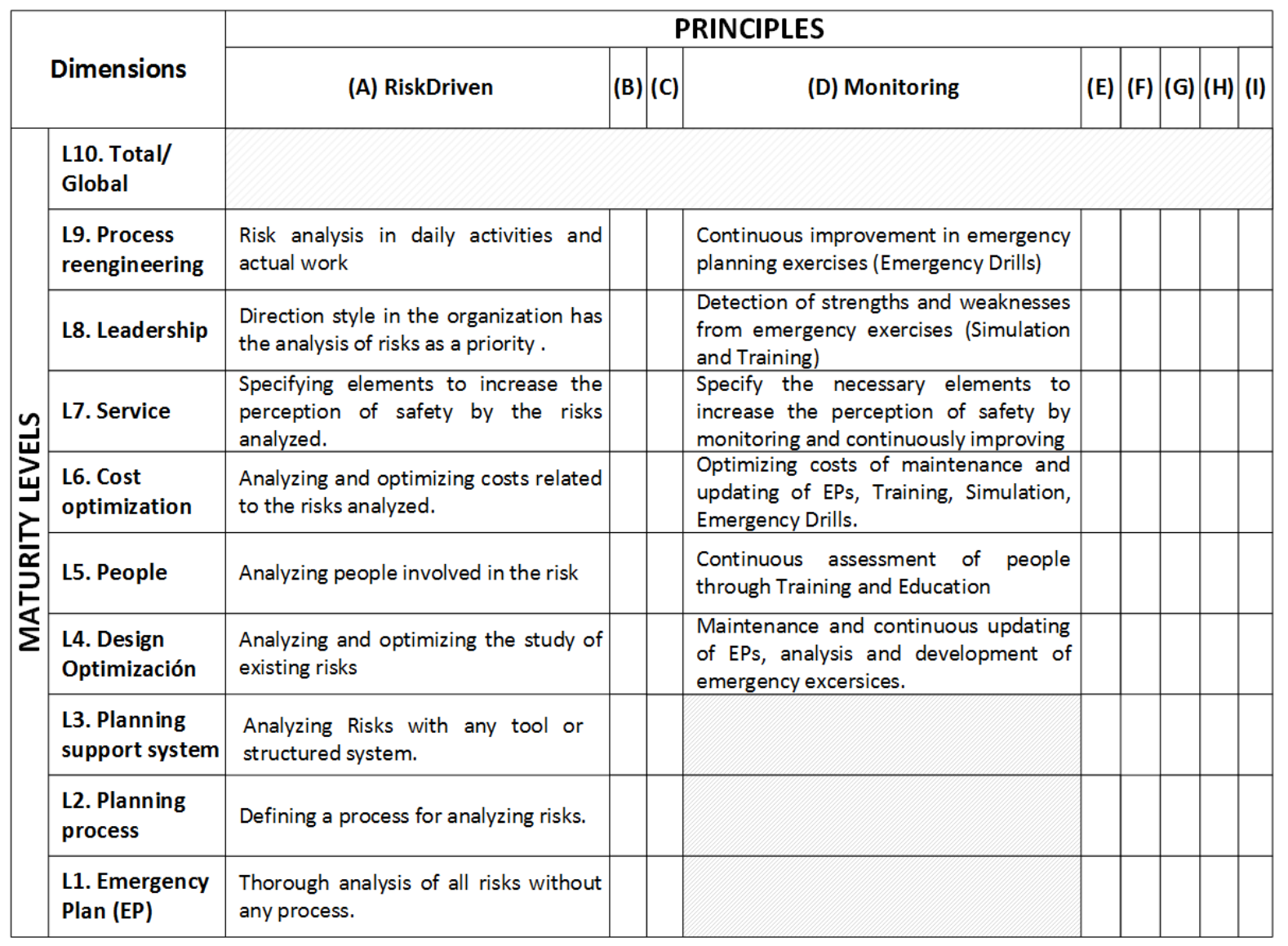

Figure 3. Maturity Levels vs.Principles

The QuEP practices. The QuEP principles have been refined as a set of practices in order to implement the assessment and improvement of the emergency plan management. The QuEP practices are activities performed as a part of the emergency plan management. We identified up to 26 practices and associated them with the different principles. The outcome is summarized in Table 4. For instance, the (A) Risk Driven principle has two related practices: "Risk Analysis" and "Optimizing requirements of risks", whereas the (D) Monitoring 
principle has four practices: "Emergency drills", "Resource improvement and maintenance", "Process improvement" and "Process for updated emergency plan".

\begin{tabular}{|c|c|}
\hline QuEP Principle & QuEP Practices \\
\hline (A) Risk Driven & $\begin{array}{l}\text { - Risk analysis (Hazard, vulnerability and capability analysis and } \\
\text { assessment). } \\
\text { - Optimizing risks. }\end{array}$ \\
\hline (B) Implementation & $\begin{array}{l}\text { - Control in the development. } \\
\text { - Cost of training and timeline. } \\
\text { - Analyze organizational resources. }\end{array}$ \\
\hline (C) Participation & $\begin{array}{l}\text { - Stakeholders involvement. } \\
\text { - Personal training. } \\
\text { - Teamwork and roles. }\end{array}$ \\
\hline $\begin{array}{l}\text { (D) Monitoring and } \\
\text { Continuous improvement }\end{array}$ & $\begin{array}{l}\text { - Emergency drills. } \\
\text { - Resource improvement and maintenance. } \\
\text { - Process improvement. } \\
\text { - Process for updated emergency plan. }\end{array}$ \\
\hline (E) Cooperation & $\begin{array}{l}\text { - Inter-organizational coordination. } \\
\text { - Coordination/Communication. }\end{array}$ \\
\hline (F) Safety People & $\begin{array}{l}\text { - Analyze customer requirements. } \\
\text { - Customer perception. }\end{array}$ \\
\hline $\begin{array}{l}\text { (G) Leadership and } \\
\text { Policies. }\end{array}$ & $\begin{array}{l}\text { - Standards and formats specification by laws. } \\
\text { - Leadership style. } \\
\text { - System responsibilities. } \\
\text { - Dissemination of emergency plan by authorities. }\end{array}$ \\
\hline (H) Results of objectives & $\begin{array}{l}\text { - Goals and vision (Objectives). } \\
\text { - Customer satisfaction. } \\
\text { - Protection to workers. }\end{array}$ \\
\hline (I) IT \& Innovation & $\begin{array}{l}\text { - Tool support. } \\
\text { - Sensor systems and alarms. } \\
\text { - Information management \& communication using IT. }\end{array}$ \\
\hline
\end{tabular}

Table 4. QuEP Principles and associated Practices

We use questionnaires to assess an organization according to QuEP principles and their associated practices, and a set of questions have been defined to assess the degree of compliance with each QuEP practice. Additionally, QuEP provides guidelines to improve the emergency plan management, i.e. to improve the implementation of the practices. Different techniques have been defined to help the organization improve its practices and, as a consequence, to increase their maturity level. 
The QuEP Questions. We give some examples of QuEP questions in Table 5 for two QuEP practices: "(RA) Risk Analysis", associated with the $(A)$ Risk Driven principle, and the "(ED) Emergency Drills" practice associated with the (D) Monitoring principle. Each QuEP question only relates to certain stakeholders, who should provide their knowledge about the requested topics.

\begin{tabular}{|c|c|c|c|c|c|}
\hline \multirow{2}{*}{$\begin{array}{l}\text { (RA) Risk Analysis Practice } \\
\text { QuEP Question }\end{array}$} & \multicolumn{5}{|c|}{ Stakeholder } \\
\hline & Org. & Pla. & Wrk. & Rsp. & Cit. \\
\hline $\begin{array}{l}\text { RA.Q1 Does the emergency plan specify the natural hazards that } \\
\text { affect the organization? }\end{array}$ & • & $\bullet$ & • & $\bullet$ & \\
\hline RA.Q2 Does the emergency plan specify the external risks? & - & - & - & - & \\
\hline $\begin{array}{l}\text { RA.Q3 Does the organization consider the costs of facilities and } \\
\text { resources related to risk prevention? }\end{array}$ & • & & & & \\
\hline $\begin{array}{l}\text { RA.Q4 Does the organization consider people's capacity in its } \\
\text { facilities? }\end{array}$ & $\bullet$ & & $\bullet$ & $\bullet$ & $\bullet$ \\
\hline $\begin{array}{l}\text { RA.Q5 Does the organization consider the most vulnerable } \\
\text { buildings/floors/zones? }\end{array}$ & • & & • & • & - \\
\hline $\begin{array}{l}\text { RA.Q6 Has the organization a good communication between } \\
\text { buildings/floors/zones? }\end{array}$ & $\bullet$ & & & $\bullet$ & \\
\hline $\begin{array}{l}\text { RA.Q7 Does the emergency plan use maps to specify the location of } \\
\text { emergency elements? }\end{array}$ & • & $\bullet$ & • & • & \\
\hline RA.Q8 Does the organization establish safety zones for evacuation? & - & & $\bullet$ & - & \\
\hline $\begin{array}{l}\text { RA.Q9 Does the organization consider the most vulnerable people } \\
\text { (children, disabled ...)? }\end{array}$ & $\bullet$ & & $\bullet$ & - & $\bullet$ \\
\hline \multicolumn{6}{|l|}{$\cdots \cdots$} \\
\hline (ED) Emergency drills Practice & \multicolumn{5}{|c|}{ Stakeholder } \\
\hline QuEP Question & Org. & Pla. & Wrk. & Rsp. & Cit. \\
\hline ED.Q1 Has the organization performed any emergency drill? When? & $\bullet$ & $\bullet$ & $\bullet$ & - & \\
\hline $\begin{array}{l}\text { ED.Q2 Does the emergency plan describe the implementation and } \\
\text { maintenance of the emergency drills according to the legal } \\
\text { regulations? }\end{array}$ & $\bullet$ & $\bullet$ & & • & \\
\hline $\begin{array}{l}\text { ED.Q3 Does the organization make public the planned emergency } \\
\text { drills to all its members? }\end{array}$ & $\bullet$ & $\bullet$ & $\bullet$ & • & - \\
\hline $\begin{array}{l}\text { ED.Q4 Does the organization perform the training and education in } \\
\text { emergency response to all its members? }\end{array}$ & $\bullet$ & & $\bullet$ & & • \\
\hline $\begin{array}{l}\text { ED.Q5 Does the organization include the costs of training and } \\
\text { education in its budget? }\end{array}$ & $\bullet$ & $\bullet$ & & & \\
\hline $\begin{array}{l}\text { ED.Q6 Does the organization perform an analysis and report on the } \\
\text { effectiveness of all cost and resources involved in an emergency drill? }\end{array}$ & $\bullet$ & $\bullet$ & & & \\
\hline
\end{tabular}

Table 5. Excerpt of QuEP Questions by Practice and Role 
The Stakeholder column in Table 5 indicates the relevant roles for each question. To assess the degree of compliance with a practice in an organization, QuEP generates a questionnaire for each role or stakeholder.

The QuEP Techniques. A set of guidelines and recommendations was identified for each practice. Organizations should follow these techniques if the practices established for each maturity level are not covered. These techniques help to make the respective practices effective. Table 6 shows some examples of techniques for the "(ED) Emergency drills" and the "(RA) Risk Analysis" practices. The techniques are also related to the QuEP questions and the QuEP framework suggests how to improve the requested item related to a practice, listing the techniques to be applied (see column QuEP Questions in Table 6). The techniques listed may differ according to the answer to the QuEP question (in closed questions).

\begin{tabular}{|c|c|}
\hline \multicolumn{2}{|l|}{ (RA) Risk Analysis Practice } \\
\hline QuEP Technique & QuEP Question \\
\hline $\begin{array}{l}\text { RA.T1 Study the types of natural hazard and external threats by location } \\
\text { and climate characteristics, occurrence and frequency. }\end{array}$ & RA.Q1, RA.Q2, ... \\
\hline $\begin{array}{l}\text { RA.T2 Perform the appropriate identification and location of different risk } \\
\text { elements that may cause an emergency. }\end{array}$ & RA.Q7, ... \\
\hline RA.T3 Analyze people's capability. & RA.Q4, ... \\
\hline RA.T4 Include maps. & RA.Q7, RA.Q6, ... \\
\hline RA.T5 Analyze resource costs. & RA.Q3, ... \\
\hline RA.T6 Analyze the most vulnerable people. & RA.Q9, ... \\
\hline RA.T7 Consider the most vulnerable buildings/floors/zones. & RA.Q5, ... \\
\hline RA.T8 Establish safe areas to ensure safety of people in an emergency. & RA.Q8, ... \\
\hline \multicolumn{2}{|l|}{$\ldots \ldots$} \\
\hline \multicolumn{2}{|l|}{ (ED) Emergency drills Practice } \\
\hline QuEP Technique & QuEP Question \\
\hline ED.T1 Perform an Emergency Drill. & ED.Q4, ... \\
\hline ED.T2 Consider the costs of training and education. & ED.Q5, ... \\
\hline $\begin{array}{l}\text { ED.T3 Describe the implementation and maintenance of the emergency } \\
\text { drills according to the legal regulations. }\end{array}$ & ED.Q2, ... \\
\hline ED.T4 Make public the planned emergency drills and its participants. & ED.Q3, ... \\
\hline ED.T5 Have an emergency drills history. & ED.Q1, ... \\
\hline $\begin{array}{l}\text { ED.T6 Write a report on the effectiveness of costs/resources involved in } \\
\text { an emergency drill. }\end{array}$ & ED.Q6, ... \\
\hline
\end{tabular}

Table 6. Excerpt of QuEP techniques by practices and related questions 
Figure 4 shows the Unified Modelling Language (UML) class diagram that illustrates the conceptual model the QuEP framework is based on. The principles (Principle class) are implemented as sets of practices (Practice class), which are in turn associated with specific maturity levels (MaturityLevel class) and performed by stakeholders (Stakeholder class). For each practice to be evaluated, a set of questions (QuEPQuestion class) has been designed for the different stakeholders. The techniques (Technique class) are part of the practices and are associated with the questions.

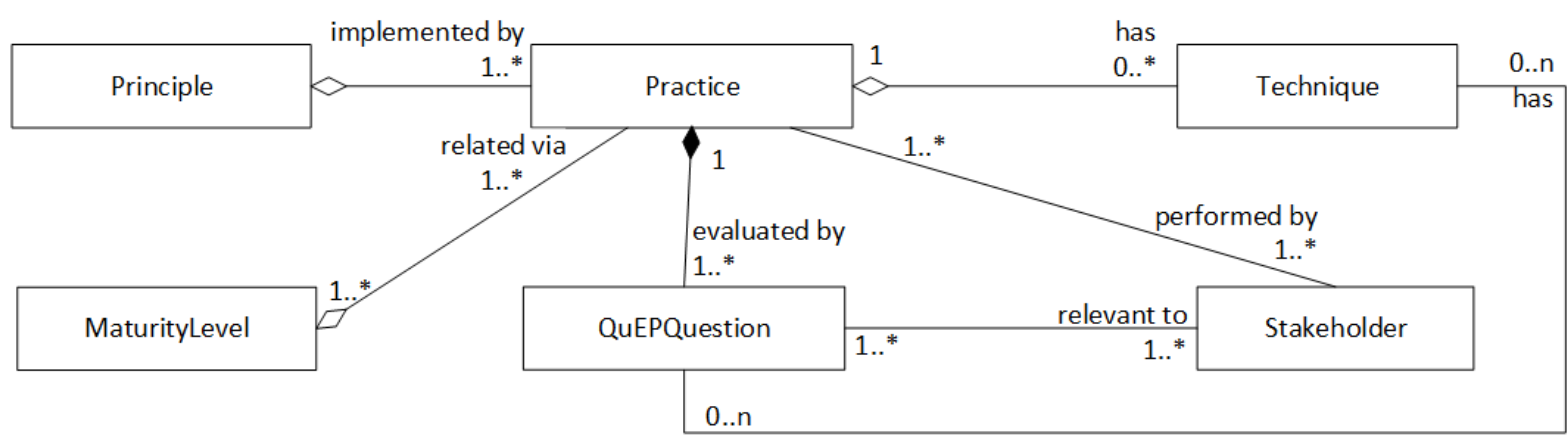

Figure 4. The QuEP Conceptual Model

\subsection{QuEP+R: Building resilience in the emergency plan management}

We have extended the QuEP framework with the aim of contributing to more resilient emergency plan management. Briefly, we have added a new dimension to QuEP, representing resilience as defined by Fiksel's framework. Figure 5 shows how Fiksel's resilience characteristics have been integrated into QuEP to make QuEP+R.

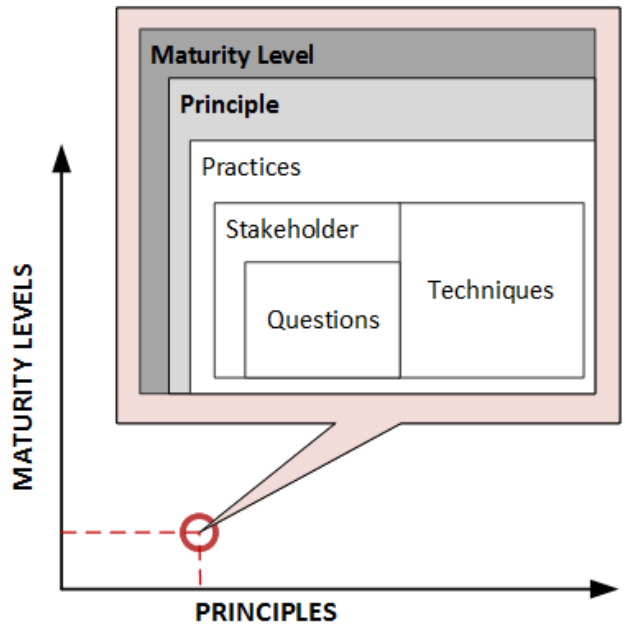

(a) QuEP

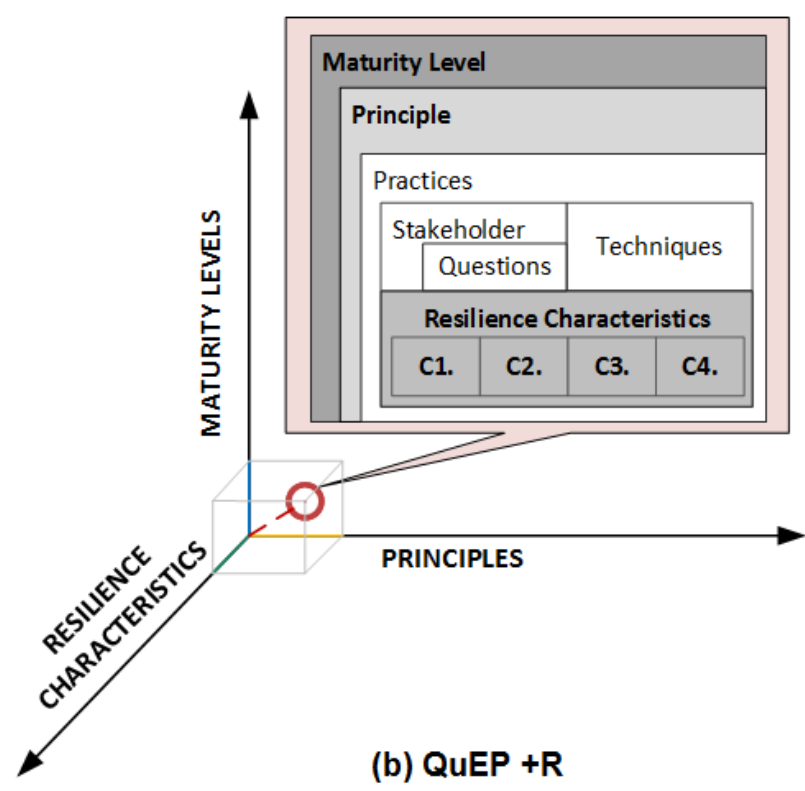

(b) QuEP +R

Figure 5. A simplified view of the extended framework QuEP to include resilience

In addition to questions and techniques defined in QuEP (see Figure 5 (a)), the resilience characteristics (diversity, efficiency, adaptability and cohesion) are included, as shown in Figure 5(b). The goal is not to replace the established QuEP principles and practices for the 
emergency plan management; rather, we are looking for complementary QuEP practices and the coordination of multiple stakeholders working towards more resilient organizations.

The QuEP conceptual model in Figure 4 has also been extended to include the resilience dimension, specifying Fiksel's resilience characteristics as instances of the new entity (ResilienceCharacteristic class), as Figure 6 shows. Notice that the resilience characteristics are associated with zero or more QuEP questions and zero or more techniques. Navigating through the relationships of the conceptual model, we can obtain the related practice and the related stakeholder, and finally, the principle and the maturity level associated with a resilience characteristic.

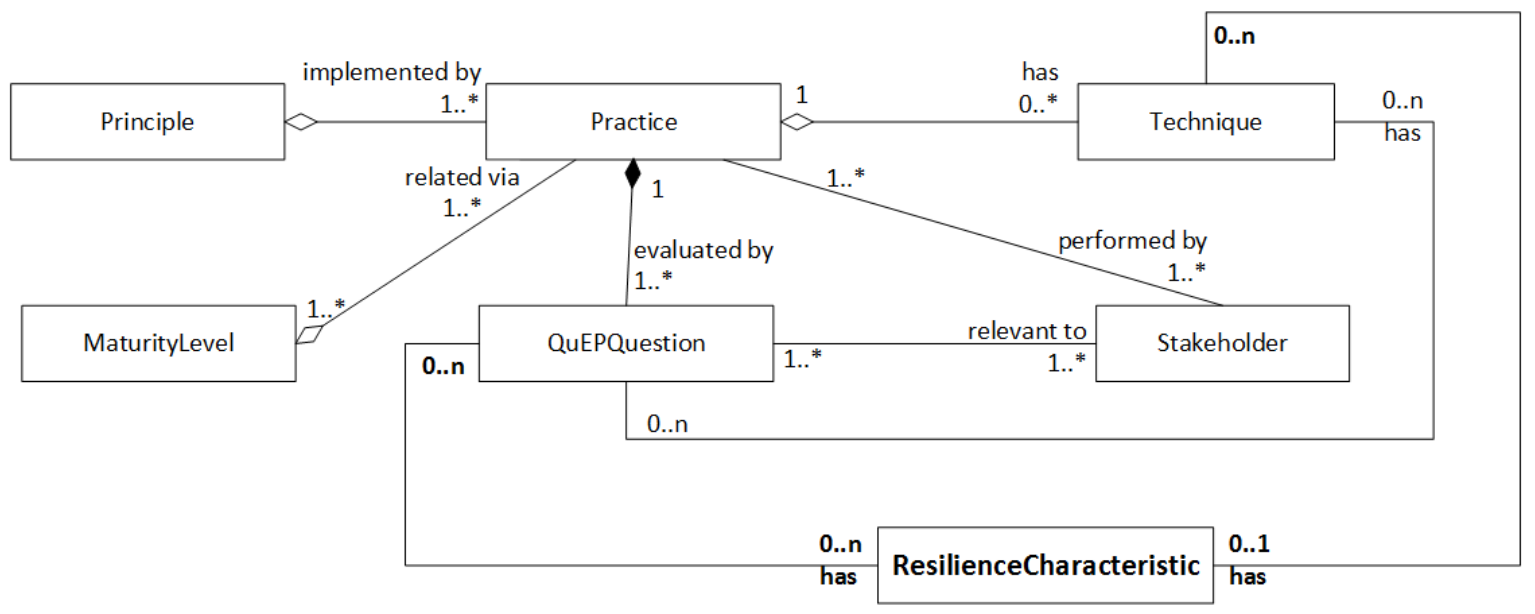

Figure 6. The QuEP+R conceptual model

The main task in the development of QuEP+R was to compose QuEP maturity levels and principles with Fiksel's resilience characteristics to find how a more resilient emergency plan management can be achieved (see Table 7). This is a two-step task, the first of which consists of re-classifying the features that emergency plans should include to enforce resilience (summarized in Table 1) and assigning them to the corresponding QuEP maturity levels. For instance, having different notations to represent the emergency response processes or customized process views are features that enforce the diversity of the emergency plan regarding the coordination dimension (Cell D1-C1 in Table 1). These features have been assigned to the L3 and L5 QuEP maturity levels, respectively. Another example is the use of Digital Libraries to increase the efficiency of the access to knowledge (Cell D2-C2 in Table 1), which has been assigned to the L7 QuEP maturity level. All the resilient characteristics related to the emergency plans (shown in Table 1) have been reclassified by QuEP maturity levels and have been listed in regular typeface in Table 7.

The second step was to complete and reinforce the features that increase the resilience of the emergency plan management as a complex organization or system. In this step, we also used Fiksel's resilient characteristics. The new features are listed in italics in Table 7 and include resource management, cost analysis, budgets, financial strategies (cost/profit), big data, learning coordination, intelligent buildings, new technologies, continuous collaboration, feedback and continuous improvement at different levels, among others. At lower QuEP maturity levels (L1 and L2), the adaptability and cohesion of the emergency plan management cannot be improved; only diversity and efficiency may be consideredin order to improve the formal knowledge included in the emergency plan and the planning activities involved. From L3 to L9, some features that increase resilience can be identified. 


\begin{tabular}{|c|c|c|c|c|}
\hline \multirow{3}{*}{$\begin{array}{l}\text { QuEP } \\
\text { Maturity } \\
\text { Levels } \\
\text { L10. }\end{array}$} & \multicolumn{4}{|c|}{ System Characteristics of Resilience for Emergency Plans Management [Fiksel] } \\
\hline & C1. Diversity. & C2. Efficiency & C3. Adaptability & C4. Cohesion \\
\hline & \multicolumn{4}{|c|}{ Search of the excellence in all the system } \\
\hline $\begin{array}{l}\text { L9. Process } \\
\text { reengineering }\end{array}$ & $\begin{array}{l}\text { - Feedback and } \\
\text { continuous } \\
\text { improvement of } \\
\text { different behaviors } \\
\text { around lower levels. } \\
\text { - Including intelligent } \\
\text { buildings and new } \\
\text { trends. }\end{array}$ & $\begin{array}{l}\text { - Feedback and } \\
\text { continuous } \\
\text { improvement of } \\
\text { efficiency around lower } \\
\text { levels. } \\
\text { - Work on intelligent } \\
\text { buildings and new } \\
\text { trends. } \\
\text { - Big Data } \\
\text { - Data Fusion }\end{array}$ & $\begin{array}{l}\text { - Feedback and } \\
\text { continuous } \\
\text { improvement of } \\
\text { flexibility to rapid } \\
\text { dynamic change } \\
\text { around lower levels. } \\
\text { - Adaptability to } \\
\text { intelligentbuildings and } \\
\text { new trends. }\end{array}$ & $\begin{array}{l}\text { - Feedback and } \\
\text { continuous } \\
\text { improvement of strong } \\
\text { linkages around lower } \\
\text { levels } \\
\text { - Continuous } \\
\text { collaboration in } \\
\text { intelligent buildings } \\
\text { and new trends. }\end{array}$ \\
\hline L8. Leadership & $\begin{array}{l}\text { - Controlrole-based } \\
\text { intra-inter } \\
\text { organizational } \\
\text { coordination levels. } \\
\text { - Controlling different } \\
\text { information and } \\
\text { communication of the } \\
\text { organization. }\end{array}$ & $\begin{array}{l}\text { - Coordination Training } \\
\text { - Resources } \\
\text { Management }\end{array}$ & $\begin{array}{l}\text { - Learning Coordination } \\
\text { - Manage resources } \\
\text { (events, risks... } \\
\text { Resources allocation) }\end{array}$ & $\begin{array}{l}\text { - Corporate culture } \\
\text { - Intra/Inter- } \\
\text { organizational } \\
\text { coordination } \\
\text { - Safety awareness } \\
\text { - Skills in problem- } \\
\text { solving and } \\
\text { communication } \\
\text { - Environment, } \\
\text { resources, and people } \\
\text { strongly coupled }\end{array}$ \\
\hline L7. Service & $\begin{array}{l}\text { - Personalized views of } \\
\text { emergency plans } \\
\text { - Bioethics and } \\
\text { biotechnology }\end{array}$ & $\begin{array}{l}\text { - Make public events } \\
\text { - Digital Libraries }\end{array}$ & $\begin{array}{l}\text { - Context-sensitive tools. } \\
\text { (Training and learning } \\
\text { friendly tools) } \\
\text { - Ambient intelligence } \\
\text { environment. }\end{array}$ & $\begin{array}{l}\text { - Safety oriented } \\
\text { information systems. } \\
\text { - Emergency context } \\
\text { integrated. } \\
\text { - Social networks } \\
\text { integrated }\end{array}$ \\
\hline $\begin{array}{l}\text { L6. Cost } \\
\text { optimization }\end{array}$ & $\begin{array}{l}\text { - Strategy for Financial } \\
\text { Emergencies (different } \\
\text { strategies:cost/profit). }\end{array}$ & $\begin{array}{l}\text { - The budget for } \\
\text { resources (Training \& } \\
\text { Simulation) } \\
\text { - Analyze cost and time. }\end{array}$ & $\begin{array}{r}- \text { Invest in new } \\
\text { technologies }\end{array}$ & $\begin{array}{l}\text { - Investment, } \\
\text { collaboration and } \\
\text { sponsorship with other } \\
\text { organizations and } \\
\text { government }\end{array}$ \\
\hline L5. People & $\begin{array}{l}\text { - Tacit Knowledge } \\
\text { - Collaboration in role- } \\
\text { based Intra/inter- } \\
\text { organizational } \\
\text { coordination levels } \\
\text { - Customized process } \\
\text { views }\end{array}$ & $\begin{array}{l}\text { - Training \& Education } \\
\text { - Procedural Validity } \\
\text { - Collaborative decision } \\
\text { support system. }\end{array}$ & $\begin{array}{l}\text { - Learning Perception } \\
\text { - Adaptive Interfaces }\end{array}$ & $\begin{array}{l}\text { - Stakeholders } \\
\text { relationships } \\
\text { - Maintain levels of } \\
\text { awareness \& } \\
\text { enthusiasm of } \\
\text { stakeholders } \\
\text { - Clusters (Strong and } \\
\text { weak circle-friends) }\end{array}$ \\
\hline $\begin{array}{l}\text { L4. } \\
\text { Optimization }\end{array}$ & $\begin{array}{l}\text { - Ontologies } \\
\text { - Different } \\
\text { devices/channels } \\
\text { - Different data sources } \\
\text { \& algorithms }\end{array}$ & $\begin{array}{l}\text { - Automatic } \\
\text { dissemination of } \\
\text { information as } \\
\text { multimedia digital } \\
\text { objects } \\
\text { - Cloud services \& } \\
\text { - ubiquitous computing } \\
\text { - Data Warehouse \& } \\
\text { Data Mining } \\
\text { - Data Science } \\
\text { - Executable response } \\
\text { processes } \\
\text { - Decision support } \\
\text { system }\end{array}$ & $\begin{array}{l}\text { - Context- } \\
\text { sensitiveness } \\
\text { - Continuous support of } \\
\text { information in real- } \\
\text { time } \\
\text { - Flexible workflow } \\
\text { languages }\end{array}$ & $\begin{array}{l}\text { - Management access to } \\
\text { Emergency context } \\
\text { - Integrated } \\
\text { communication } \\
\text { system } \\
\text { - Transfer, fast, and } \\
\text { reliablecommunication } \\
\text { of information } \\
\text { - Information } \\
\text { consolidated from data } \\
\text { sources }\end{array}$ \\
\hline $\begin{array}{l}\text { L3. Planning } \\
\text { support system }\end{array}$ & $\begin{array}{l}\text { - Contextual Knowledge } \\
\text { - Different notations to } \\
\text { represent the } \\
\text { Emergency Response } \\
\text { Processes }\end{array}$ & $\begin{array}{l}\text { - Multimedia digital } \\
\text { objects } \\
\text { - Assessment of } \\
\text { response processes }\end{array}$ & $\begin{array}{l}\text { - Case management } \\
\text { modelling } \\
\text { - Allocation of resource } \\
\text { buffer for critical } \\
\text { situations }\end{array}$ & $\begin{array}{l}\text { - Emergency } \\
\text { Management Support } \\
\text { System }\end{array}$ \\
\hline $\begin{array}{l}\text { L2. Planning } \\
\text { process }\end{array}$ & & - Planning Activities & & \\
\hline $\begin{array}{l}\text { L1. Emergency } \\
\text { Plan (EP) }\end{array}$ & - Formal Knowledge & & & \\
\hline
\end{tabular}

Table 7. Identifying Resilience for Emergency Plan Management by QuEP Maturity Levels 
For instance at L3, the planning support system may be improved by supporting the contextual information and/or the formal specifications of emergency response processes (L3 - C1.Diversity) or using multimedia digital objects to store the emergency plan components and/or including assessments of the response processes (L3 - C2.Efficiency), or using case management modelling and/or allocation of resources for critical situations (L3 - C3.Adaptability) or providing an integrated emergency management support system (L3 C4.Cohesion). Similarly, Table 7 shows how to improve the resilience of each maturity level up to L9, which identifies the feedback and continuous improvement of proposals around lower levels and/or the inclusion of intelligent building technologies as key features in increasing resilience. The L10 maturity level is the search for excellence in the entire system. We can conclude that higher QuEP maturity levels lead to more resilient emergency plan management and that the resilience of the organization is enforced.

Having identified the features which enforce the resilience of the emergency plan management, we have identified the resilient features covered by the QuEP principles and practices and those that are not. As mentioned above (Subsection 5.1), to assess an organization according to QuEP practices, we use questionnaires composed of QuEP questions and provide guidelines to improve the emergency plan management through QuEP techniques. We have therefore identified the QuEP questions that have a relationship with the resilient features specified in Table 7 and classified them as: questions which measure a resilient feature, and those related to resilience but need to be reformulated and extended. On the other hand, new QuEP questions are proposed to measure the resilient features not covered by the existing ones.

\begin{tabular}{|c|c|c|c|}
\hline QuEP & Resilience & Question & Technique \\
\hline \multirow{4}{*}{$\begin{array}{l}\text { Maturity Level } \\
\text { L7. Service } \\
\text { Principle } \\
\text { (D) Monitoring } \\
\text { Practice } \\
\text { Emergency } \\
\text { drills }\end{array}$} & $\begin{array}{l}\text { C1. Diversity. } \\
\text { Personalized views } \\
\text { of emergency plan }\end{array}$ & $\begin{array}{l}\text { C1.Qx Was the building maps' visualization } \\
\text { during the emergency drill easy? }\end{array}$ & $\begin{array}{l}\text { ED.Tx.C1 Making building maps } \\
\text { available to participants during the } \\
\text { emergency drill. }\end{array}$ \\
\hline & $\begin{array}{l}\text { C2. Efficiency } \\
\text { Make public events }\end{array}$ & $\begin{array}{l}\text { ED.Q3 Does the organization make public } \\
\text { the planned emergency drills to all its } \\
\text { members? }\end{array}$ & $\begin{array}{l}\text { ED.T4 Make the planned emergency } \\
\text { drills and its participants public. }\end{array}$ \\
\hline & $\begin{array}{l}\text { C3. Adaptability } \\
\text { Context- } \\
\text { sensitive tools }\end{array}$ & $\begin{array}{l}\text { ED.Q4 + C3. Does the organization perform } \\
\text { the training and education to emergency } \\
\text { response to all its members supported by } \\
\text { friendly-tools? }\end{array}$ & $\begin{array}{l}\text { ED.Tx.C3 Train all its members in } \\
\text { emergency response using friendly } \\
\text { tools. }\end{array}$ \\
\hline & $\begin{array}{l}\text { C4. Cohesion } \\
\text { Social Networks } \\
\text { integrated }\end{array}$ & $\begin{array}{l}\text { ED.Q3 + C4.Does the organization make } \\
\text { public the planned emergency drills to all its } \\
\text { membersthrough social networks? }\end{array}$ & $\begin{array}{l}\text { ED.T4+C4. Publish the planned } \\
\text { emergency drills and its participantsin } \\
\text { social networks. }\end{array}$ \\
\hline QuEP & Resilience & Question & Technique \\
\hline $\begin{array}{l}\text { Maturity Level } \\
\text { L2.Planning } \\
\text { process } \\
\text { Principle } \\
\text { (A) Risk Driven } \\
\text { Practice } \\
\text { Risk Analysis }\end{array}$ & $\begin{array}{l}\text { C2. Efficiency } \\
\text { Planning Activities }\end{array}$ & $\begin{array}{l}\text { RA.Q1 Does the emergency plan specify } \\
\text { the natural hazards that affect the } \\
\text { organization? } \\
\text { RA.Q.2 Does the emergency plan specify } \\
\text { the external risks? }\end{array}$ & $\begin{array}{l}\text { RA.T1 Study the types of natural } \\
\text { hazard and external risks by location } \\
\text { and climate characteristics, occurrence } \\
\text { and frequency }\end{array}$ \\
\hline
\end{tabular}

Table 8. Examples of QuEP Questions and Techniques related to Resilience in Emergency Plans Management

Following the "Risk Analysis" and "Emergency drills" practices, Table 8 shows some examples of QuEP questions and techniques related to resilience. Improving the efficiency of the planning activities, corresponding to "Risk Analysis" practice at the L2 maturity level is 
an example of resilience in QuEP, where the questions and associated techniques were previously identified, as we can see in Table 5 (RA.Q1 and RA.Q2 questions) (represented in regular typeface in Table 8). However, for the "Emergency drills" practice, the framework has been extended with new questions and techniques (in italics). For instance, to assess and improve the diversity characteristic with personalized views of emergency plans, a new question has been added to QuEP+R (C1.Qx Was the building maps' visualization during the emergency drill easy?) and its associated technique (ED.Tx.C1 Making buildings maps available to participants during the emergency drill.). However, to improve the cohesion characteristic with integration through social networks, both the existing QuEP question (ED.Q3+C4 in Table 5) and the technique have been extended.

\subsection{Supporting the process with the QuEP-tool}

We are currently designing and implementing a tool to assist analysts in the use of QuEP and QuEP+R,in the form of an organizational assessment questionnaire that contains a set of instances of the QuEPQuestion class shown in Figure 5.A set of questions was designed for each practice to be evaluated. When all the instances of the QuEPQuestion have been created, they are assembled in the questionnaires given to the stakeholders. Different stakeholders will receive different questionnaires, since their views on emergency plan management will differ. The responses to the questionnaires are stored in the tool's repository for further processing (see below).

The first version of the QuEP-tool is now available (Nuñezet al., 2016b) and an iterative development process is currently in operation to generate new versions. An example of mockups built during the tool design stage can be seen in Figure 7. In Figure 7(a) a user has been logged into the system in the role of planner and in Figure 7(b) the user logged in is a responder. Note that different questions are used for each role.

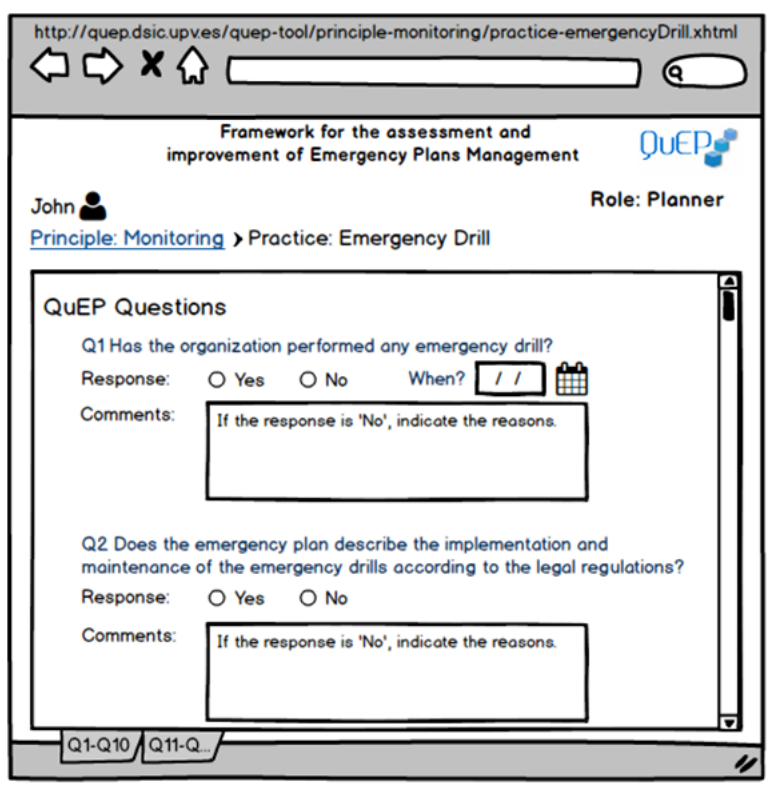

(a) QuEP Questions for the assessment of Emergency Drill practice

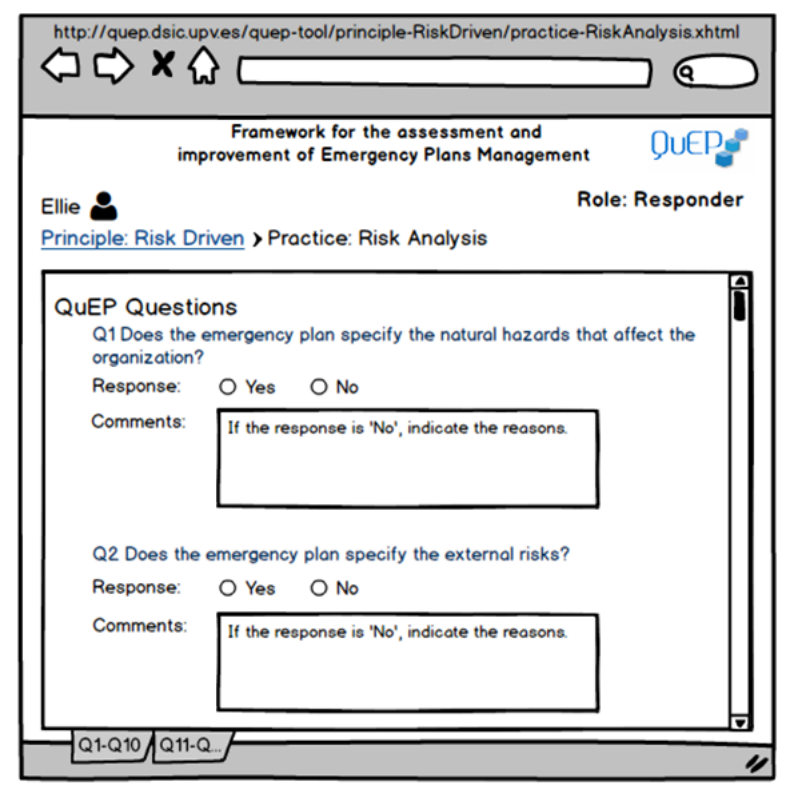

(b) QuEP Questions for the assessment of Risk Analysis practice

Figure 7. Mockup of QuEP-Questions 


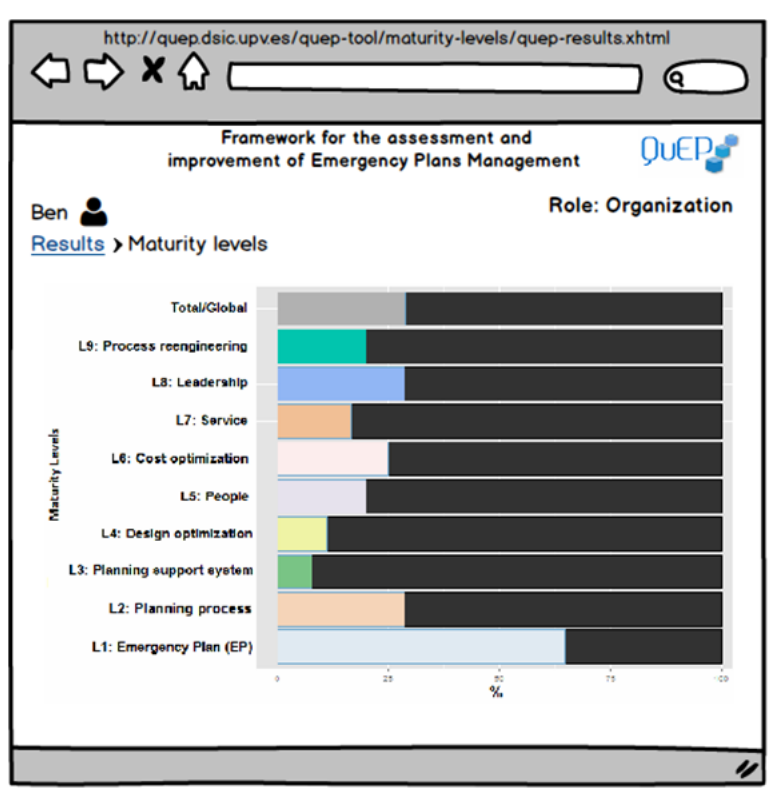

(a) Results of maturity levels reached by organization

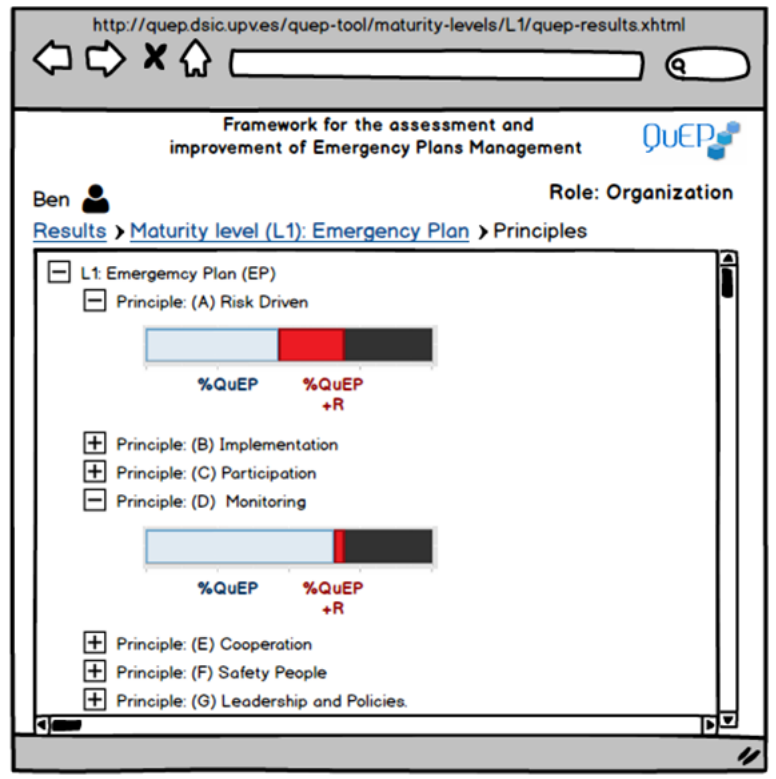

(b) Results of Principles by maturity level

Figure 8. Mockup of QuEP Results

The QuEP-tool gives an assessment of the organization after the users have entered their responses. The QuEP results format can be seen in Figure 8. The screens shown are those of a user playing the role of an organization. Figure 8(a) represents a general view of the degree of achievement for each maturity level. When the user clicks on a level bar, the screen shown in Figure 8(b) appears, containing the results corresponding to the principles associated with the maturity level. The levels of achievement of each principle are given according to both the QuEP (white bar) and QuEP+R (red bar). These results are obtained from an algorithm which weights the responses to each question according to the characteristics of the practices, principles, levels and resilience. This algorithm can be seen in Table 9. Briefly, it can be summarized as follows:

First, we calculate the question value $\mathrm{Qv}_{\mathrm{l}}=\mathrm{x}_{\mathrm{l}}$; where $x$ is the average responses value $x=$ $\bar{x}=\frac{\sum_{l=1}^{n} x_{l}}{n}, n$ is the number of responses and $l$ specifies the question index. If the Question is part of the Resilience Characteristic, we analogously calculate the resilient question value $Q v R_{l}=x_{l}$. Once the values have been obtained for each question, we proceed to calculate the practice values by calculating the average $P r_{k}=\overline{Q v_{l}}$, where $k$ is the practice index, and in the same way the practice value with resilience $\operatorname{Pr} R_{k}=\overline{Q v R_{l}}$. We then calculate for each level the average value level for $L v R_{i}=\overline{P R_{j}}$, where $i$ is the level index and $j$ is the practice index for each level, and the average value level with resilience $L_{v R_{i}}=\overline{P R_{j}}$. Finally, we check whether the level value is greater than a pre-established threshold. "If LvTotal $_{\mathrm{i}}>t$ then $\mu(\mathrm{L})=\{$ tolerable when $\mathrm{L}>t$; no tolerable when $L<t\}$; ; where $\mathrm{t}$ is the threshold; $\mathrm{t}=$ 0.5 and we also check other constraints. The constraints are the different situations required for the different questions. For example, the number of the response options that a question requires. According to this algorithm, the measured resilience is the weighted value of each practice. These values may be grouped by principle and level as a merge operation. 


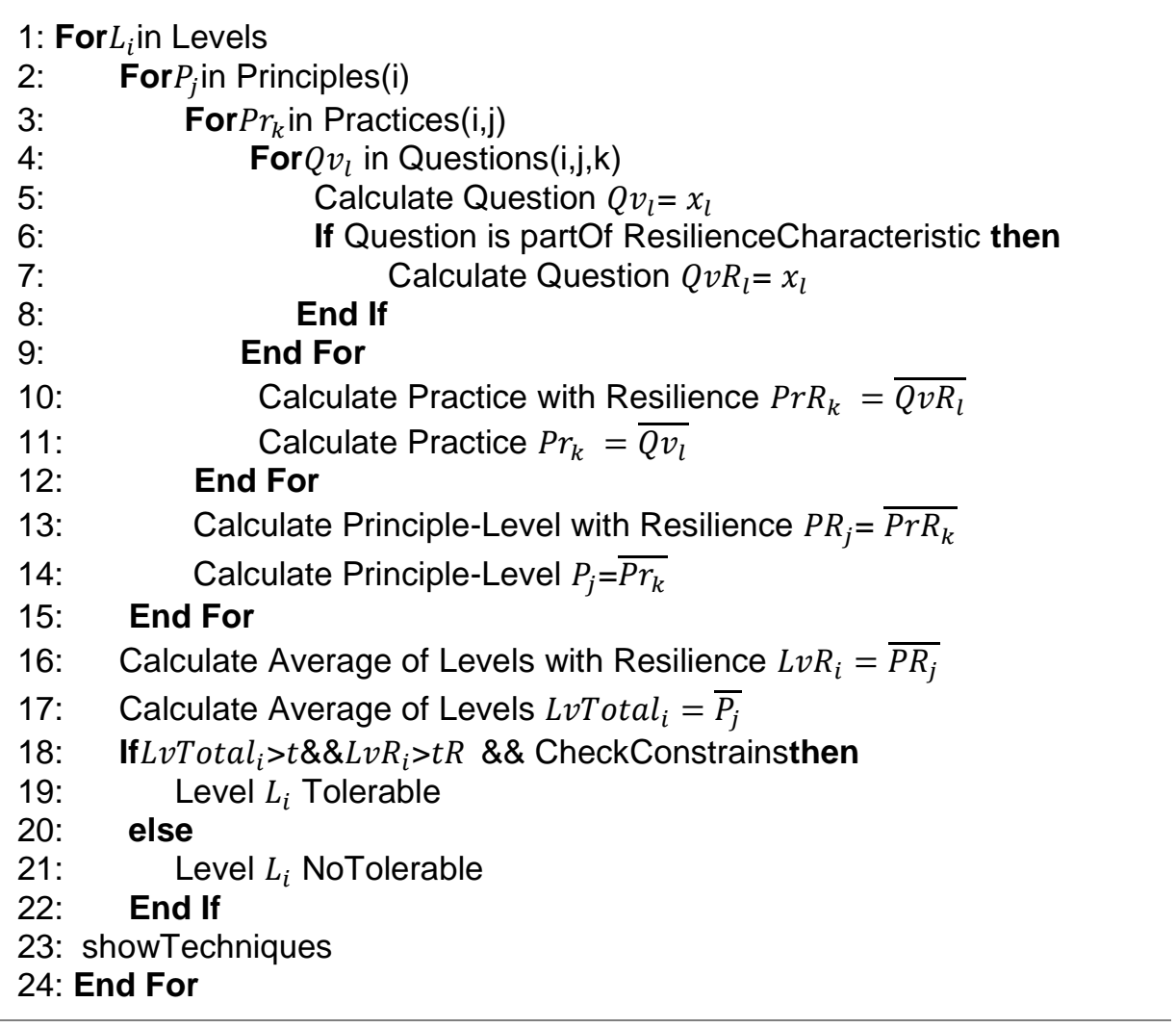

Table 9. Algorithm used to calculate the result by maturity level in QuEP

\section{Conclusions and further work}

Emergency planning and resilience building have many goals in common, but there are also many differences between the two. While the former is mostly scenario-driven and aims at increasing emergency preparedness against crisis situations by defining response procedures, acquiring emergency equipment, and defining training programs, among other activities, the latter follows a more analytic approach to evaluate and improve the capacity of an organization to recover after a crisis. In this paper, we used a combination of both approaches and took the emergency plan as the reference asset. We analyzed how an emergency plan contributes to what we called theoretical resilience, i.e. the extent to which the emergency plan includes the knowledge necessary to respond to potential disruptions. This theoretical resilience must be transformed into actual resilience by the correct management of the emergency plan via the policies defined by the organizations.

To understand how an emergency plan's content and structure can affect its resilience, we combined the dimensions of emergency management, as identified by Canós et al., with the characteristics of resilient systems as laid down by Fiksel. In this way we identified a number of the features of emergency plans that contribute to their resilient characteristics. This allowed us to define different roadmaps for (theoretical) resilience-building in organizations. Most of these features are related to advances in Information Technologies (e.g. the use of flexible process languages, multimedia, and/or personalization).

For more than a decade our primary goal has been to develop better emergency plans by providing planners with better tools. However, we are aware that an advanced emergency plan by itself is not necessarily an indicator of a highly resilient organization. This is why we 
took a step further and looked at the assessment of emergency plan management as another key element in the resilience-building processes. A good emergency plan is only useful if it is managed properly, but the question is: what does "properly" mean? And, unfortunately, deficient emergency plan management is more common than one would expect. Emergency plans are often left on a shelf and remain unused until an incident occurs. In other cases, preparedness can be improved by preventive actions, such as emergency drills, which allow the partial testing of the emergency plans and facilitate the detection of inconsistencies that otherwise would only be discovered in actual emergencies.

The QuEP framework for the assessment of emergency plan management was used to find relationships between the QuEP components (mainly maturity levels and principles) and resilient characteristics. As a result, we were able to identify a significant number of practices and techniques that help organizations to identify, anticipate, and respond to catastrophic events, reduce the probability of their occurring, or lessen their impact and duration. This extended framework is called QuEP $+R$, our conceptual proposal to reinforce the resilience in an organization. QuEP+R is supported by a tool currently under development. We have provided some information on the tool's interface and have produced the first operational prototype.

As for further work, we plan to finalize a double validation of QuEP+R. First, the QuEP questionnaires were evaluated by experts from different areas of emergency management following the Delphi method (Linstone and Turoff, 2011). The experts were selected from several organizations and provided with a description of the QuEP framework, plus the questionnaires associated with it. We also provided them with an assessment questionnaire in which they evaluated the questions in the QuEP questionnaire, as described in (Nuñez et al., 2016a). The results of the first round of the experts' evaluation are at present being processed and their answers will determine whether the QuEP question associated with a practice is approved, reformulated or removed. On the other hand, we plan to apply and evaluate $\mathrm{QuEP}+\mathrm{R}$ in different organizations around the world, including end-users. In the mid-term, we expect to have a web-based assessment service that organizations and governments will be able to use to build resilience by improving their emergency plan management processes.

\section{Acknowledgments}

The work of M. C. Penadés and J. H. Canós was partially funded by MINECO under grant CALPE (TIN2015-68608-R) and A.G. Núñez received support from SENESCYT scholarship program of the Republic of Ecuador.

\section{References}

Adger, W.N., 1997. Sustainability and social resilience in coastal resource use. CSERGE working paper series, Centre for Social and Economic Research on the Global Environment, University of East Anglia, Norwich and University College London, UK.

Adolph, L., Lafrenz, B., Grauel, B., 2012.Safety Management Systems, Safety Culture and Resilience engineering: Comparison of Concepts, Proceedings HFES Europe Chapter Conference Toulouse. pp. 269-276. 
Alexander, D., 2005. Towards the development of a standard in emergency planning Towards the development of a standard in emergency planning. Disaster Prevention and Management: An International Journal, Vol. 14, 158-175. doi:10.1108/09653560510595164

Alexander, D.E., 2013. Resilience and disaster risk reduction: an etymological journey. Natural Hazards and Earth System Sciences 13, 2707-2716. doi:10.5194/nhess-132707-2013

Baharmand, H., Meesters, K., 2016. A multidisciplinary perspective on supporting community disaster resilience in Nepal. Proceedings of the 13th International Conference on Information Systems for Crisis Response and Management (ISCRAM 2016). Rio de Janeiro, Brazil, May 2016. 1-11.

Berggren, P., Johansson, B.J.E., Ekström, E., 2016. Resilience through training - assessing cognition in teams. Proceedings of the 13th International Conference on Information Systems for Crisis Response and Management (ISCRAM 2016). Rio de Janeiro, Brazil, May 2016.

Berke, P., Godschalk, D., 2009. Searching for the Good Plan: A Meta-Analysis of Plan Quality Studies, Journal of Planning Literature, 23, 227-240.

Berke, P., Smith, G., Lyles, W., 2012. Planning for Resiliency: Evaluation of State Hazard Mitigation Plans under the Disaster Mitigation Act, Natural Hazards Review, 13, 139_ 149.

Bhamra, R., Dani, S., Burnard, K., 2011. Resilience: the concept, a literature review and future directions. International Journal of Production Research. 49, 5375-5393. doi:10.1080/00207543.2011.563826

Blanchard, B.W., 2008. Guide to Emergency Management and Related Terms, Definitions, Concepts, Acronyms, Organizations, Programs, Guidance, Executive Orders \& Legislation. Past Present FEMA. URL http://training.fema.gov/EMIWeb/edu/docs/terms and definitions/Terms and Definitions.pdf (accessed on Feb 23, 2016).

Brown, K., 2013. Resilience, Development and Global Change. Routledge.

Bruinsma, G.W.J., 2010.Adaptive Workflow Simulation of Emergency Response. University of Twente. http://doi.org/10.3990/1.9789036529990

Camisón, C., 1998. Total quality management and cultural change: a model of organisational development. International Journal of Technology Management. 16(4-6), 479-493. doi: 10.1504/ijtm.1998.002668.

Camisón, C., Cruz, S., González, T., 2007.Quality management: concepts, approaches, models and systems. Pearson/Prentice Hall, Madrid; Santiago, Chile.

Canós, J.H., Alonso, G., Jaén, J., 2004.A multimedia approach to the efficient implementation and use of emergency plans. MultiMedia, IEEE, 11(3), 106-110. doi: 10.1109/MMUL.2004.2

Canós, J.H., Penadés, M.C., Solís, C., Llavador, M., 2010.Using Spatial Hypertext to Visualize Composite Knowledge in Emergency Responses. Proceedings of the 7th International Conference on Information Systems for Crisis Response and Management. 1-10. doi:10.4018/jiscrm.2011070104 
Canós, J.H., Borges, M.R., Penadés, M.C., Gómez, A., Llavador, M., 2013.Improving emergency plans management with SAGA. Technological Forecasting and Social Change, 80(9), 1868-1876. doi: http://dx.doi.org/10.1016/j.techfore.2013.02.014.

Canós, J. H., Sánchez, J., Orts, V., Penadés, M.C., Gómez, A., Borges, M., 2014. Turning emergency plans into executable artifacts. Proceedings of the 11th International Conference on Information Systems for Crisis Response and Management. 496-500.

Charantimath, P.M., 2011. Total Quality Management. Pearson Education India.

Crichton, M.T., Ramsay, C.G., Kelly, T., 2009. Enhancing organizational resilience through emergency planning: Learnings from cross-sectoral lessons. Journal of Contingencies and Crisis Management. 17, 24-37. doi:10.1111/j.1468-5973.2009.00556.x

Dean, J.W., Bowen, D.E., 1994. Management Theory and Total Quality: Improving Research and Practice through Theory Development. The Academy of Management Review. doi:10.2307/258933

Diniz, V., Borges, M.R., Gomes, J.O., Canós, J.H., 2008. Decision Making Support in Emergency Response. Encyclopedia of Decision Making and Decision Support Technologies. I, 184-191. doi: 10.4018/978-1-59904-843-7.ch021.

dos Reis, M.I., Borges, M.R., Gomes, J.O., 2008 Identifying Resilience in Emergency Response Stories. 3nd Resilience Engineering International Symposium

Fiksel, J., 2003. Designing Resilient, Sustainable Systems. Environmental science \& technology, 37(23). 5330-5339. doi:10.1021/es0344819

Fiksel, J., 2006. Sustainability and resilience: toward a systems approach. Sustainability: Science, Practice, \& Policy, 2(2). doi: 10.1109/EMR.2007.4296420

Fiksel, J., 2012. A systems view of sustainability: The triple value model. Environmental Development. 138-141. doi:10.1016/j.envdev.2012.03.015

Fiksel, J., Goodman, I., Hecht, A., 2014. Resilience: Navigating toward a Sustainable Future. Solutions 5, 38-47. URL http://www.thesolutionsjournal.com/node/237208. (accessed on Dec 3, 2015).

Fletcher, D., Sarkar, M., 2013. Psychological resilience: A review and critique of definitions, concepts, and theory. European Psychologist. 18, 12-23. doi:10.1027/10169040/a000124

Folke, C., Carpenter, S., Walker, B., Scheffer, M., Elmqvist, T., Gunderson, L., Holling, C.S., 2004. Regime Shifts, Resilience, and Biodiversity in Ecosystem Management. Annual Review of Ecology, Evolution, and Systematics. 35, 557-581. doi:10.1146/annurev.ecolsys.35.021103.105711.

Galton, A., Worboys, M., 2011. An Ontology of Information for Emergency Management. Proceedings of the 8th International Conference on Information Systems for Crisis Response and Management (ISCRAM 2011). 1-10. Lisboa, Portugal, May 2011.

Hamel, Gary and Valikangas, L., 2003. The quest for resilience. Harvard business review. 81(9), 52-65.

Han, J., Micheline, K., Pei, J., (2011) Data Mining Concepts and Techniques. 3rd Edition Elsevier. 
Hofmann, M., Sackmann, S., Betke, H., 2013. A Novel Architecture for Disaster Response Workflow Management Systems. Proceedings of the 10th International ISCRAM Conference. 338-343. Baden-Baden, Germany, May 2013

Holling, C.S., 1973. Resilience and Stability of Ecological Systems. Annual Review of Ecology and Systematics 4, 1-23. doi:10.1146/annurev.es.04.110173.000245

Hollnagel, E., Woods, D.D., 2006. Prologue: Resilience Engineering Concepts. Resilience engineering. Concepts and precepts. 1-16.

Huber, G.J., Righi, A.W., Gomes, J.O., De, P.V.R., 2016. Firefighting emergency response exercise - an analysis of standardization and resilience. Proceedings of the 13th International Conference on Information Systems for Crisis Response and Management (ISCRAM 2016). Rio de Janeiro, Brazil, May 2016.

Kean, T.H., Hamilton, L.H., Ben-Veniste, R., Fielding, F.F., Gorelick, J.S., Gorton, S., Kerrey, B., Lehman, J.F., Roemer, T.J., Thompson, J.R., 2004. The 9/11 Comission Report. The 9/11 Comisssion Report 58.

Klein, R.J.T,Nicholls, R.J., Thomalla, F., 2003. 'Resilience to natural hazards: How useful is this concept?' Environmental Hazards. 5. pp. 35-45.

Li, L., Goodchild, M.F., 2010. "The Role of Social Networks in Emergency Management". International Journal of Information Systems for Crisis Response and Management (IJISCRAM). 2, 48-58. doi:10.4018/jiscrm.2010100104

Lindsay, B.R., 2012. Federal emergency management: A brief introduction, in: Congressional Research Service, Library of Congress.

Linstone, H., Turoff, M., 2011. Delphi: A Brief Look Backward and Forward. Technological Forecasting and Social Change, 78(9): 1712-19. doi: 10.1016/j.techfore.2010.09.011.

Llavador, M., Letelier, P., Penadés, M.C., Canós, J.H., Borges, M.R., Solís, C., 2006.Precise yet flexible specification of emergency resolution procedures. Proceedings of 3rd International Conference on Information Systems for Crisis Response and Management (ISCRAM 2006). Newark (NJ), USA, May 2006.

Mandal, S.K., 2009. Total Quality Management - Principles And Practice, 1E. Vikas Publishing House Pvt Ltd.

Manyena, S.B., 2006. The concept of resilience revisited. Disasters 30, 433-450. doi:10.1111/j.0361-3666.2006.00331.x

McEntire, D.A., Fuller, C.,Johnston, C.W., Weber, R., 2002. 'A Comparison of Disaster Paradigms: The Search for a Holistic Policy Guide'. Public Administration Review. 62(3). pp. 267-281.

Mendonça, D., 2007. Decision support for improvisation in response to extreme events: Learning from the response to the 2001 World Trade Center attack. Decision Support Systems. 43(3), 952-967. doi:10.1016/j.dss.2005.05.025

Meyerson, R., 2012. A Tool for evaluating plan quality of local Government emergency management response plans.

Miller, R., 2006. Hurricane Katrina: Communications \& Infrastructure Impacts. NATIONAL DEFENSE UNIV FORT MCNAIR DC. 191-203. URL http://csis.org/images/stories/HomelandSecurity/071022_Chap5-

KatrinaCommunicationsAndInfrastructurelmpacts.pdf. (accessed on Oct 3, 2015). 
Mills, K.L., 2003. Computer-Supported Cooperative Work. Encyclopedia of library and information science (2nd edition). doi: 10.1007/10606.1573-7551.

Núñez, A.G., Penadés, M.C., Canós, J.H., Borges, M.R, 2015. Towards a Total Quality Framework for the Evaluation and Improvement of Emergency Plans Management. Proceedings of the 12th International Conference on Information Systems for Crisis Response \& Management (ISCRAM 2015). Kristiansand, Norway, May 2015.

Núñez, A.G., Penadés, M.C., Canós, J.H., 2016a. QuEP: Building a Continuous Improvement of Emergency Plans Management. Proceedings of the 13th International Conference on Information Systems for Crisis Response and Management (ISCRAM 2016). Rio de Janeiro, Brazil, May 2016.

Núñez, A.G., Penadés, M.C., Canós, J.H., 2016b.“A tool supporting for the Assessment and Improvement of Emergency Plans Management”. JISBD. 591-604. Salamanca, Spain, Sept 2016 (in Spanish)

Nwachukwu, T., Robinson, M., 2011. The role of diversity in building adaptive resilience. London: Arts Council England. URL http://www.artscouncil.org.uk/media/uploads/pdf/Diversity_and_adaptive_resilience_pu blic.pdf (accessed on Dec 01, 2015).

Oakland, J. S., 2014. Total quality management and operational excellence: text with cases. Routledge. http://dx.doi.org/10.4324/9781315815725.

Penadés, M. C., Canós, J. H., Borges, M.R., Vivacqua, A. S., 2011.A product line approach to the development of advanced emergency plans. In Proc. of the 8th International Conference on Information Systems for Crisis Response and Management (ISCRAM 2011).

Sakurai, M., Gonzalez, J.J., Watson, R.T., 2016. A Capital Model for Disaster Resilience, in: Proceedings of the 13th International Conference on Information Systems for Crisis Response and Management (ISCRAM 2016). Rio de Janeiro, Brazil, May 2016.

Sánchez, J., Carsí, J.A., Penadés, M.C., 2015.“A case management environment for flexible emergency resolution”. JISBD. 1-14. Santander, Spain, Sept 2015 (in Spanish)

Schulz, A., Paulheim, H., 2013. Mashups for the Emergency Management Domain. In Semantic Mashups. 237-260. Springer Berlin Heidelberg. doi:10.1007/978-3-64236403-7_8

Sigel, M., 2015. Standards To Enhance Organizational Resilience. URL http://www.disasterresource.com/articles/08p_026.shtml (accessed on Oct 5, 2015).

Solís, C., Ali, N., 2008. ShyWiki-A spatial hypertext wiki. Proceedings of the 4th International Symposium on Wikis.10. ACM. doi:10.1145/1822258.1822272

Timmerman P., 1981. Vulnerability, resilience and the collapse of society: a review of models and possible climatic applications. Institute for Environmental Studies, University of Toronto, Canada

Turnbull, M., Sterrett, C.L., Amy, H., 2013. Toward Resilience: A Guide to Disaster Risk Reduction and Climate Change Adaptation. International Review of Public Administration. 18(3), 257-260. doi:10.3362/9781780440026

Turner, B., 1976. The Organizational and Interorganizational Development of Disasters. Administrative Science Quarterly. 378-397. doi:10.2307/2391850. 
Turoff, M., Chumer, M., Van de Walle, B., Yao, X., 2004.The design of a dynamic emergency response management information system (DERMIS). JITTA: Journal of Information Technology Theory and Application, 5(4), 1. doi: 10.4028/www.scientific.net/AMR.605-607.1855

Turoff, M., Hiltz, S.R., Bañuls, V.A., Van Den Eede, G., 2013. Multiple perspectives on planning for emergencies: An introduction to the special issue on planning and foresight for emergency preparedness and management. Technological Forecasting and Social Change, Planning and Foresight Methodologies in Emergency Preparedness and Management 80, 1647-1656. doi:10.1016/j.techfore.2013.07.014.

UNISDR (United Nations International Strategy for Disaster Risk Reduction), 2005. Hyogo Framework for 2005-2015: Building the Resilience of Nations and Communities to Disasters. https://www.unisdr.org/we/coordinate/hfa. Accessed on 04 september 2016.

UNISDR: Terminology on Disaster Risk Reduction. United Nations International Strategy for Disaster Risk Reduction, Geneva, 2009. http://www.unisdr.org/we/inform/publications/7817. Accessed on 30 july 2016.

Villena-Román, J., Luna-Cobos, A., González-Cristóbal, J.C., 2014, TweetAlert: Semantic Analytics in Social Networks for Citizen Opinion Mining in the City of the Future. 2nd International Workshop on Personalization in eGovernment Services and Applications. URL http://ceur-ws.org/Vol-1181/pegov2014_paper_01.pdf. (accessed on Jan 5, 2016).

Walker, B., Carpenter, S., Anderies, J., Abel, N., Cumming, G., Janssen, M., Pritchard, R., 2002. Resilience management in social-ecological systems: a working hypothesis for a participatory approach. Conservation ecology. 6(1), 14. URL http://www.consecol.org/vol6/iss1/art14. (accessed on Nov 8, 2015).

Werner, E., 1995. Resilience in development. Current directions in psychological science. 4, $81-85$

Zhou, H., Wang, J., Wan, J., Jia, H., 2010. Resilience to natural hazards: a geographic perspective. Natural Hazards 53, 21-41. doi:10.1007/s11069-009-9407-y

Zobel, C.W., 2011. Representing perceived tradeoffs in defining disaster resilience. Decision Support Systems 50, 394-403. doi:10.1016/j.dss.2010.10.001 